Int. J. Dev. Biol. 55: 823-834

doi: $10.1387 / \mathrm{ijdb} .113359 \mathrm{jt}$

\title{
Sialylation regulates galectin-3/ligand interplay during mammary tumour progression - a case of targeted uncloaking
}

\author{
JOANA-TAVARES DE OLIVEIRA ${ }^{1,2}$, AUGUSTO-JOSÉ DE MATOS ${ }^{2,3}$, ANA L. SANTOS $^{1}$, \\ RITA PINTO' ${ }^{1}$, JOANA GOMES ${ }^{1}$, VENCESLAU HESPANHOL ${ }^{4}$, ROGER CHAMMAS ${ }^{5}$, AKI MANNINEN ${ }^{6}$, \\ EMERSON S. BERNARDES ${ }^{1}$, CELSO ALBUQUERQUE REIS' ${ }^{1}$, GERARD RUTTEMAN7 and FÁTIMA GÄRTNER ${ }^{*, 1,2}$

\begin{abstract}
${ }^{1}$ Institute of Molecular Pathology and Immunology (IPATIMUP), University of Porto, Portugal, ${ }^{2}$ Instituto de Ciências Biomédicas de Abel
\end{abstract} \\ Salazar (ICBAS), University of Porto, Portugal, ${ }^{3}$ UMIB, University of Porto, ${ }^{4}$ Medical Faculty of the University of Porto, Porto, Portugal, ${ }^{5}$ Labo- \\ ratory of Experimental Oncology, Faculdade de Medicina, Universidade de São Paulo, São Paulo, Brazil, ${ }^{6}$ Cell Biology, Biocenter Oulu, Oulu \\ Centre for Cell-Matrix Research, Department of Medical Biochemistry and Molecular Biology, University of Oulu, Finland and ${ }^{7}$ Department of \\ Clinical Sciences of Companion Animals, Faculty of Veterinary Medicine, Utrecht University, Utrecht, The Netherlands
}

\begin{abstract}
Galectin-3 is involved both in facilitating detachment of cells from primary tumour sites and favouring cancer cell adhesion and survival to anoikis in the blood stream. The mechanisms behind these apparently contradictory roles of the lectin have not yet been resolved. In order to investigate possible interplays between galectin-3 and its ligands underlying their role in the metastatic process, we examined mucin-1 (MUC1) and epidermal growth factor receptor (EGFR), well-known galectin-3 ligands, as well as galectin-3-binding site expression in a series of spontaneous canine malignant mammary tumours (CMMT) and a metastatic CMMT cell line. Despite the fact that CMMT cells expressed MUC1 and EGFR homogeneously over their plasma membrane, intravascular tumour cells, positive for galectin-3, expressed MUC1 and EGFR in a more focal membrane localization. Moreover, MUC1 overexpression in primary CMMT was present in parallel with down-regulation of galectin-3. Furthermore, in the CMT-U27 cell line, galectin-3 knock-down led to increased MUC1 expression, while MUC1 knock-down led to down-regulation of the lectin. Finally, removal of sialic acid from both CMMT and CMT-U27 xenograft samples exposed galectin-3-ligands throughout the tumour tissue, whereas these ligands were only present in galectin-3-positive invading cells in untreated samples. Interestingly indeed, we show that in vessel-invading cells, there is interaction between galectin-3 and the T antigen in vivo. We therefore hypothesized that loss of galectin-3 and sialylation-related masking of its ligands, in conjunction with their overexpression in specific tumour cell subpopulations, are crucial in regulating adhesive/de-adhesive events in the progression and invasive capacity of metastatic cells.
\end{abstract}

KEY WORDS: galectin-3, galectin-3 ligand, sialylation, metastasis, mammary tumour

\section{Introduction}

The metastatic process involves a complex series of coordinated events leading to distant metastases - the main cause of tumour-related death (Chambers et al., 2002). Crucial steps in this process include detachment of tumour cells from primary sites, by loss of homotypic (between cancer cells) and heterotypic cellextracellular matrix (ECM) adhesion and survival of tumour emboli in the blood stream, which in contrast, requires homotypic adhesion between tumour cells (Orr and Wang, 2001). The prospect of better understanding the adhesion/de-adhesion capacity of tumour cells is paramount to in turn understand tumour progression and

\footnotetext{
Abbreviations used in this paper: CMMT, canine malignant mammary tumours; CRD, carbohydrate recognition domain; ECM, extracellular matrix; EGFR, epidermal growth factor receptor; Gal3/AP probe, galectin-3/alkaline phosphatase probe; ICAM-1, intercellular adhesion molecule 1; MAL, Maackia Amurensis Lectin; MUC1, Mucin-1; PLA, proximity ligation assay; RCPs, rolling circle products; RUNX, Runt-related gene family; shRNA, short hairpin RNA; SNA, Sambucus Nigra Agglutinin; T antigen, Thomsen-Friedenreich antigen.
}

\footnotetext{
*Address correspondence to: Fátima Gärtner. Rua Dr. Roberto Frias s/n, 4200-465 Porto, Portugal. Tel: +3512-2557-0700. Fax: +3512-2557-0799. e-mail: fgartner@ipatimup.pt
} 


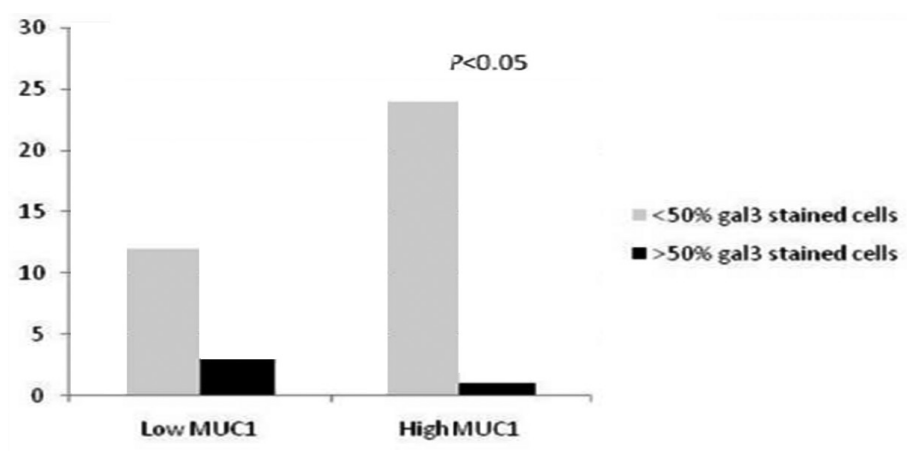

Fig. 1. Mucin1 (MUC1) is overexpressed in a series of canine malignant mammary tumours (CMMT) with galectin-3 down-regulation. MUC1 immunohistochemical staining was analyzed in a series of 40 CMMT, and tumours were compared according to the percentage of MUC1 and galectin-3-expressing tumour cells. Most CMMT presented MUC1 staining in more than $50 \%$ of tumour cells, while the majority of these tumours presented galectin-3 expression in less than $50 \%$ of tumour cells. There was a significant difference $(P<0.05)$ by Pearson chi-square test.

metastasis. Galectin-3 is a member of the family of carbohydrate binding proteins ( $\beta$-galactoside-specific lectins) that has been implicated in multiple wide spanning roles such as, cell-cell and cell-ECM adhesion, angiogenesis promotion, cell proliferation and apoptosis resistance, the latter actions ultimately facilitating tumour progression and metastasis (Liu and Rabinovich, 2005). To date, galectin-3 up- or down-regulation is, for reasons still unknown, dependent not only on tumour type but also on specific localization of tumour cells (Liu and Rabinovich, 2005). Recently, we reported on the down-regulation of galectin-3 and galectin-3-binding-sites in canine malignant mammary tumours (CMMT). This observation indicated a possible role for a decrease of galectin-3/galectin 3-binding sites in the detachment and migration of tumour cells from primary tumours. In contrast, in vessel-invading cells galectin-3 and its binding-sites were up-regulated supporting a role for such an increase in the metastatic process (de Oliveira et al., 2010).

Galectin-3 has multiple well-known ligands co-implicated in different steps of carcinogenesis (Liu and Rabinovich, 2005). Mucin-1 (MUC1) and epidermal growth factor receptor (EGFR) are among these and play a fundamental role in cancer progression and invasion (Kufe, 2009, Salomon et al., 1995). MUC1 is a large highly glycosylated membrane-associated protein expressed in the apical surface of normal epithelial cells (Kufe, 2009). Aberrant expression of MUC1 has been associated to poor prognosis in several types of cancer (Reis et al., 1998; Sipaul et al., 2011), including canine mammary cancer and human breast cancer (de Oliveira et al., 2009; Kufe, 2009). An abnormal under-glycosylated form of MUC1 is overexpressed in scattered distribution throughout the membrane of cancer cells (Kufe, 2009). In these cells, the mucin carries truncated glycan structures with terminal galactose or $\mathrm{N}$-acetylgalactosamine often being sialylated. Such is the case of the cancer associated Thomsen-Friedenreich antigen ( $T$ antigen), Gal $\beta 1-3 \mathrm{GalNac}$, i.e. core 1 dissacharide, recognized by galectin-3 (Yu et al., 2007). The T antigen is generated by the T-synthase, initiating the synthesis of core 1-derived O-glycans (Seko et al., 1996). The core 1 dissacharide is a substrate for a number of sialyltransferases, which synthesize different forms of the sialylated T antigen, including ST3Gall (Picco et al., 2010), ST6GalNacl and ST6GalNacll (Marcos et al., 2004). Recently, our group has also reported that sialylation is a prevalent type of glycosylation in CMMT (Pinho et al., 2009a). The presence of sialic acid can inhibit cell-cell interactions by masking carbohydrate ligands thus blocking receptor recognition (Powell et al., 1987). In cancer MUC1 promotes tumour cell detachment from primary sites by inhibiting cell-cell and cell-ECM adhesion, through its large size and through negative repulsive charges conferred by the presence of sialic acid (Kufe, 2009). However, in vessels, galectin-3 induces MUC1 clustering on the tumour cell surface by binding $T$ antigen. This exposes adhesion molecules such as inter-cellular adhesion molecule 1 (ICAM-1) that facilitate interaction between EGFR
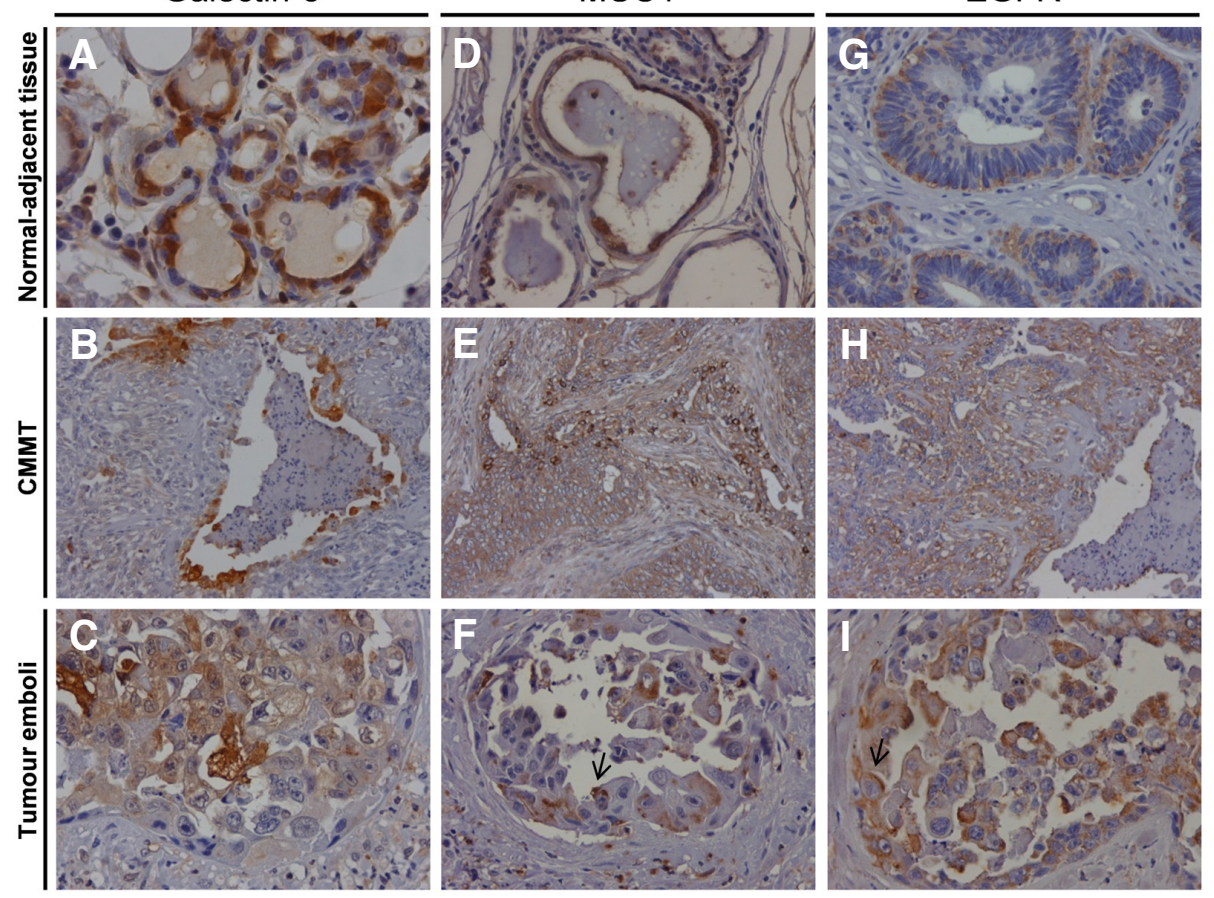

Fig. 2. MUC1 and epidermal growth factor receptor (EGFR) are differentially expressed in the membrane and cytoplasm in a series of CMMT. Photomicrographs depict galectin-3, MUC1 and EGFR immunostaining (brown colour) with haematoxylin counterstain in malignant CMT. Galectin-3 is expressed in normal-adjacent tissue (A) (x630 magnification) but its expression is decreased in malignancy (B) (x400 magnification) with the exception of among others, intravascular tumour cells (C) (x400 magnification). In normaladjacent tissue MUC1 is expressed predominantly in the apical membrane (D) (x630 magnification); in CMMT MUC1 is expressed more focally in the membrane in cytoplasmic, vesicular and whole membrane patterns (E) (x400 magnification) and consistently in intravascular tumour cells (arrow) (F) (x630 magnification). In normal-adjacent tissue EGFR is expressed in the basolateral membrane(G) (x630 magnification); in CMMT, however, EGFR is expressed all over the membrane and cytoplasm (H) (x400 magnification). Tumour cellemboliexpress EGFR more focally at the membrane (arrow) (I) (x400 magnification). 
tumour and endothelial cells (heterotypic interactions) (Zhao et al., 2009). Furthermore, in vessel-invading cells, MUC1 clustering by galectin-3 enables E-cadherin-mediated homotypic aggregation hence promoting survival over anoikis (Zhao et al., 2010).

EGFR is a member of the growth factor receptor family of tyrosine kinase receptor proteins, expressed in the basolateral membrane of the normal epithelial cells. EGFR expression reportedly is associated to poor prognosis in a range of epithelial cancers although this issue is controversial with respect to human breast cancer (Salomon et al., 1995; Klijn et al., 1992). EGFR signalling regulates several cellular functions that promote resistance to apoptosis and cell survival (Salomon et al., 1995; Burgess et al., 2003). In addition to its canonical ligand, EGFR can be activated by other proteins, including mucins, which contain EGF-like domains (Couto et al., 1996). Besides a reported direct interaction between MUC1 and EGFR (Kufe, 2009), MUC1-EGFR bridging by galectin-3 has been demonstrated in vitro using breast cancer cell lines (Ramasamy et al., 2007). Notably, the presence of both MUC1 and EGFR was recently shown in peripheral blood samples of dogs bearing CMMT (da Costa et al., 2010).

In this study we aimed to determine the mechanisms underlying the role of galectin-3 in tumour cells adhesion/ de-adhesion during the progression of CMMT. To test the relationship of the lectin with the levels and patterns of expression of its ligands MUC1 and EGFR, we used two experimental settings: 1) histochemistry, co-expression and Proximity ligation assay (PLA) interaction studies in a spontaneously occurring CMMT series; 2) Galectin-3 co-precipitation with MUC1 and EGFR and a short hairpin RNA(shRNA) strategy to knock-down galectin-3 and MUC1 in a CMMT metastatic cell line. In primary tumours, on the one hand, down-regulation of galectin-3 is associated with MUC1 overexpression (in turn significantly associated to vascular invasion and distant metastases) and the two are broadly not co-localized. Notably, an increase in MUC1 levels of expression is observed upon galectin-3 knock-down in the CMT-U27 cell line. On the other hand, galectin-3 is co-expressed at the cell membrane with EGFR and MUC1, by vessel-invading tumour cells, and interacts with the mucin via T antigen. Moreover, a decrease in galectin-3 levels of expression is observed upon MUC1 knock-down in the CMT-U27 cell line. We also analysed the effects of sialylation in modulating the availability of galectin-3-ligands during tumour progression in spontaneous CMMT and in an experimental nude mice model of CMMT. Removal of sialic acid greatly increased galectin-3 binding to primary tumours in both models. Our data demonstrate an important role of the levels and glycosylation status of galectin-3 ligands in regulating the lectin's functions in the complex multistage process of cancer metastasis.

\section{Results}

MUC1 expression in a CMMT series is up-regulated in metastatic cases, concomitant with a galectin-3 dual expression: generalized down-regulation in primary tumour vs. up regulation in tumour emboli and cells surrounding necrotic areas

In order to investigate a possible association between galectin-3 and its ligand MUC1, the immunohistochemical expression of the mucin was studied in a series of 40 cases of spontaneous CMMT and compared to previous analyses of galectin-3 expression (de Oliveira et al., 2010).

The majority of cases (25) showed MUC1 overexpression, with more than $50 \%$ of the cells being stained. Only fifteen cases expressed MUC1 in less than $50 \%$ of the cells. In contrast, there were only 4 CMMT cases with more than $50 \%$ cells stained for galectin-3. Therefore, we found a significant $(P<0.05)$ difference between galectin-3 and MUC1 expression in primary CMMT (Fig. 1). Concerning the pattern of expression, galectin-3 was found in normal-adjacent mammary epithelium (Fig. 2A) but was drastically down-regulated in the primary tumours (Fig. 2B). However an interesting, localized up-regulation of the lectin was consistently observed in well-defined areas, mainly in tumour emboli (Fig. 2C). Normal-adjacent mammary epithelium expressed MUC1 predominantly in the cytoplasm and at the apical membrane (Fig. 2D), whereas CMMT cells expressed MUC1 mainly in a cytoplasmic and vesicular pattern throughout the primary tumour cells (Fig. 2E). A total of 10 cases presented distant metastases. In these, MUC1
A
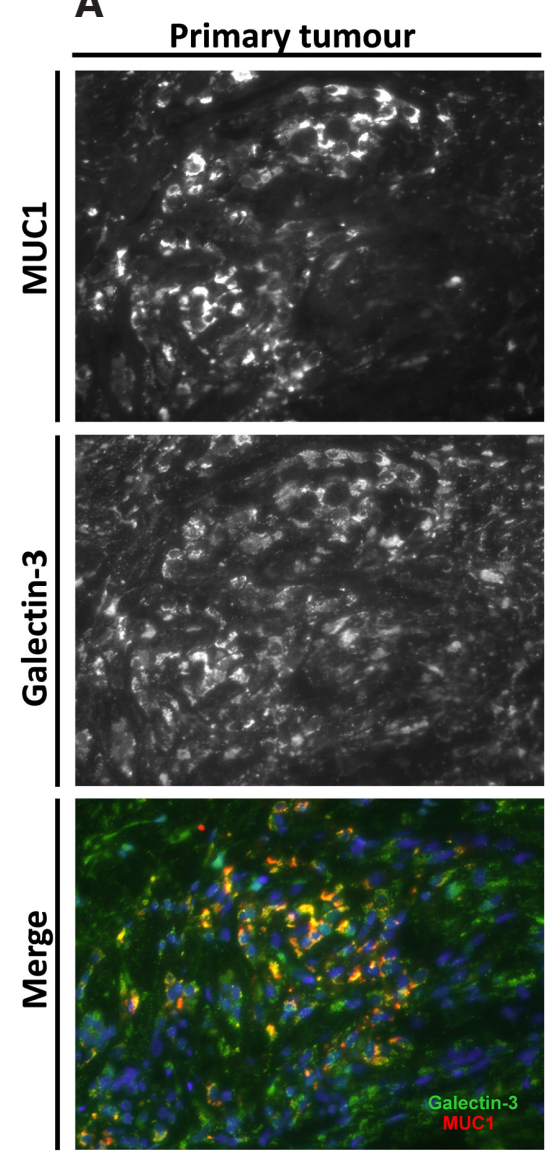

B
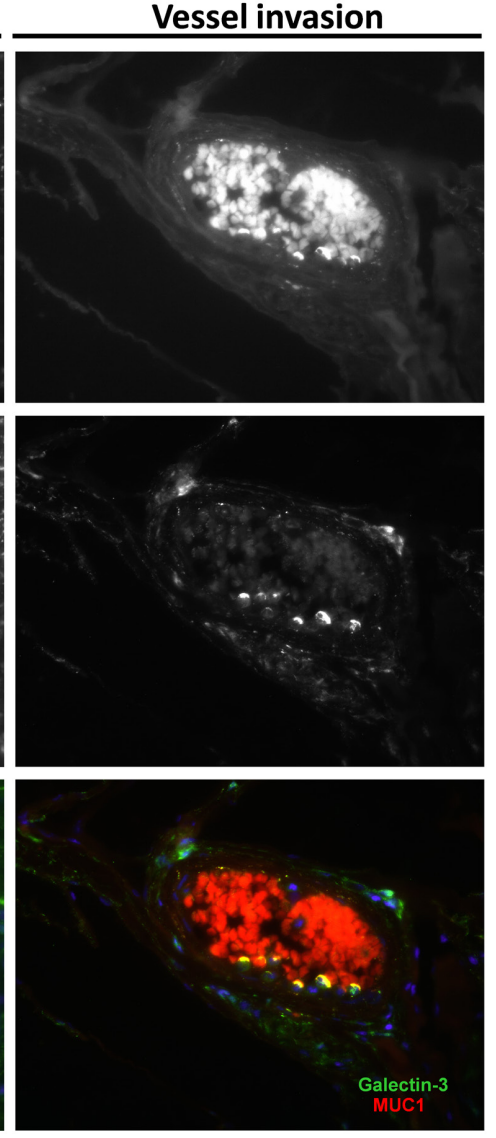

Fig. 3. Galectin-3 is co-expressed with MUC1 in cells at the vessel vicinity and in vessel-invading cells in CMMT. Co-localization was assessed by double-labelling immunofluorescence using anti-MUC1 and galectin-3 antibodies. (A) Co-localization between MUC1 (red colour) and galectin-3 (green colour) was frequently observed in cells with particularly aggressive characteristics focally. (B) Intravascular tumour cells strongly co-expressed (yellow colour) MUC1 and galectin-3 focally at the cell membrane. Photomicrograph magnifications 630x. 
overexpression ( $\geq 50 \%$ ) was more common than in cases without distant metastases, $(p=0.000)$ (Table 1). Thirteen cases presented vascular invasion. MUC1 overexpression was also significantly associated to this feature $(p=0.019)$ (Table 1). Furthermore, MUC1 expression in vessel-invading cells was focally localized at the cell membrane (Fig. 2F). These results in a primary CMMT series indicate that MUC1 overexpression (and subcellular localization), which occurs in parallel with galectin-3 generalized down-regulation, plays an important role in metastasis.

\section{EGFR expression is up-regulated in CMMT intravascular tumour cells and viable cells adjacent to necrotic areas paralleling that of galectin-3}

Next, in order to compare EGFR expression to that of galectin-3 we performed immunohistochemical studies in the same CMMT series. Thirty-six CMMT cases were positive for EGFR expression. Of these, twenty-one cases expressed EGFR in less than $50 \%$ of the cells, whereas 15 showed EGFR expression in more than $50 \%$ of the cells. In CMMT, normal-adjacent mammary tissue expressed EGFR in the basolateral membrane (Fig. 2G). When present in malignant cells, EGFR expression was observed mainly in cytoplasmic and vesicular patterns (Fig. 2H). Furthermore, EGFR expression was observed consistently surrounding necrotic areas. In fact, tumours without necrosis, a classical hallmark of aggressiveness, had statistically significant lower expression levels of EFGR than tumours with necrosis ( $p=0.002$ ) (Table 2). Interestingly, intravascular tumour cells also showed enhanced EGFR expression focally at the cell membrane (Fig. 2I). Galectin-3 expression paralleled that observed for EGFR in the same cell subpopulations as previously shown (de Oliveira et al., 2010). These results indicate a possible joint role of EGFR and galectin-3 in CMMT, in the survival process of tumour cells under stress conditions.

Galectin-3 is co-expressed with MUC1 and EGFR in intravascular tumour cells of CMMT and is present in both EGFR and MUC1 immunoprecipitates

Galectin-3 facilitates the interaction between MUC1 and EGFR in breast cancer cells in vitro (Ramasamy et al., 2007). In order to assess co-expression between galectin-3 and its ligands in vivo, we performed double-labelling immunofluorescence studies in CMMT cases with vascular invasion. When present in the primary tumour, galectin-3 co-expressed with MUC1 mainly in cells of particularly aggressive characteristics (Fig. 3A). Interestingly, in intravascular tumour cells, galectin-3 co-expressed with MUC1 focally at the cell membrane (Fig. 3B). Likewise, co-expression between galectin-3 and EGFR was also observed in intravascular tumour cells (Fig. 4).

In order to further assess the interplay between galectin-3 and its ligands we took advantage of using two canine mammary tumour
A
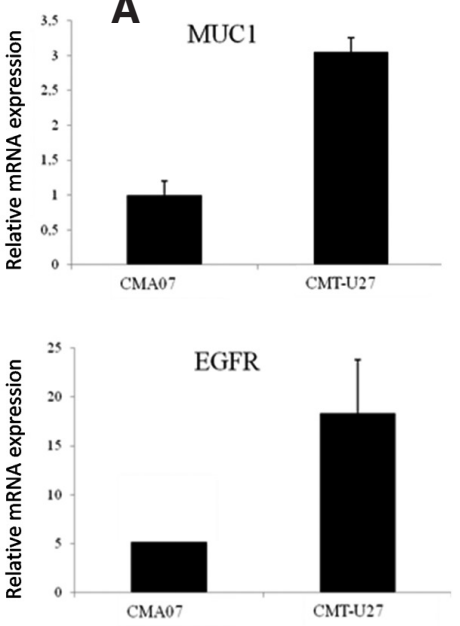

B
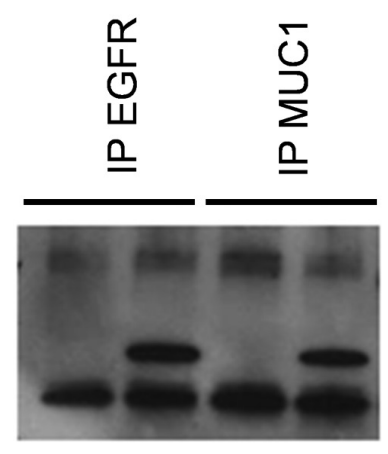

$-37 \mathrm{KDa}$ $-25 \mathrm{KDa}$

CMA07 CMT-U27 CMA07 CMT-U27

IB: anti-galectin-3

Fig. 5. CMT-U27 overexpresses MUC1 and EGFR and exhibits physical interactions between galectin-3 and its ligands when compared to CMA07 benign cell line. (A) Data from real-time PCR for MUC1 and EGFR using RNA from CMAO7 and CMT-U27 cells shows that their levels are decreased in the benign when compared to the malignant cell line. cDNA contents were normalized on the basis of predetermined levels of $18 S$. The results represent the mean $\pm S D$ of triplicate samples in one of three similar experiments. (B) Lysates from both cell lines cells were immunoprecipitated with anti-MUC1 and anti-EGFR. The precipitates were mmunoblotted with the anti-galectin-3 antibody. Galectin-3 was present both in MUC1 and EGFR precipitates of the CMT-U27 cell line.

cell lines as a model: the CMA07 benign cell line and CMT-U27 metastatic cell line. Firstly, the levels of MUC1 and EGFR expression were compared between the two cell lines. CMA07 shows decreased expression of both MUC1 and EGFR when compared to CMT-U27 (Fig. 5A,B). Lysates from these cell lines were immunoprecipitated with anti-MUC1 and anti-EGFR antibodies. The obtained MUC1 and EGFR precipitates were subsequently immunoblotted with an anti-galectin-3 antibody. Galectin-3 was present both in MUC1 and EGFR precipitates (Fig. 5B). Altogether these results imply that, in CMMT, galectin-3 might interact with MUC1 and EGFR in certain dynamic states such as vessel-invasion and other stress-enduring locations (necrosis vicinity) and suggest a role for such interactions in the metastatic process of those tumours.

\section{MUC1 and galectin-3 seem to function in a feedback regulatory loop in the CMT-U27 metastatic cell line}

MUC1 has been observed to up-regulate galectin-3 expression by a glycosylation-dependent posttranscriptional mechanism in human breast cancer cells (Ramasamy et al., 2007). In order to probe a similar role for MUC1 in CMMT, we performed MUC1 knock-down in the CMT-U27 cell line, which endogenously expresses both MUC1 and galectin-3, and evaluated its effects on galectin-3 expression. A decrease in galectin-3 mRNA expression was observed
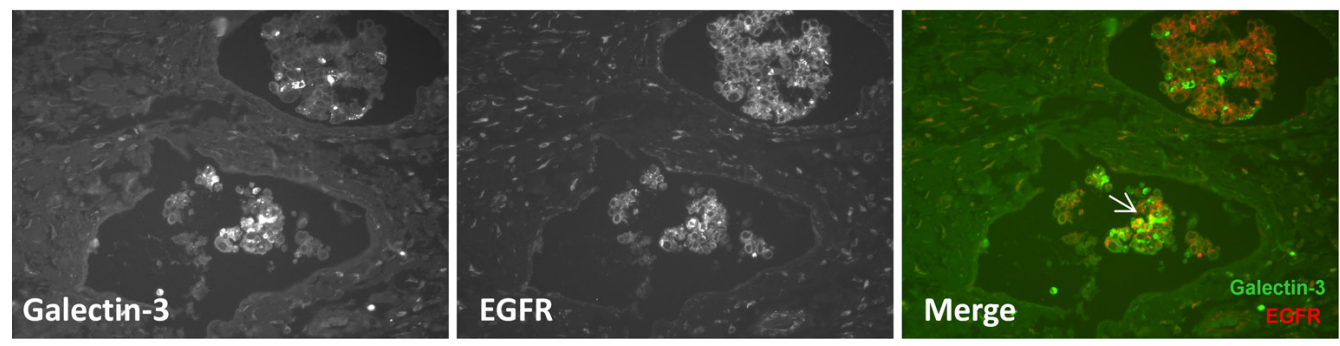

Fig. 4. Galectin-3 is co-expressed with EGFR in intravascular tumour cells of CMMT. Co-expression was assessed by double-labelling immunofluorescence us ing anti- EGFR and galectin-3 antibodies. Co-expression (yellow colour) between EGFR (red colour) and galectin-3 (green colour) was observed in vessel-invading tumour cells of CMMT (arrow). Photomicrograph magnifications 200x. 
TABLE 1

\section{RELATIONSHIP BETWEEN MUC1 EXPRESSION, DISTANT METASTASIS AND VASCULAR INVASION IN MALIGNANT CANINE MAMMARY TUMOURS}

\begin{tabular}{|c|c|c|c|c|c|c|}
\hline & & \multicolumn{4}{|c|}{$\begin{array}{l}\text { Number (and \%) of tumours showing MUC1 } \\
\text { immunostaining in the stated percentage of cells }\end{array}$} & \multirow[t]{2}{*}{$p$ value } \\
\hline & & $<25 \%$ & $25-50 \%$ & $50-75 \%$ & $>75 \%$ & \\
\hline \multicolumn{6}{|c|}{ Vascular invasion $(n=37)$} & 0.019 \\
\hline No & $24(64.9 \%)$ & $2(8.3 \%)$ & $9(37.5 \%)$ & $11(45.9 \%)$ & $2(8.3 \%)$ & \\
\hline Yes & $13(35.1 \%)$ & $0(0.0 \%)$ & $2(15.3 \%)$ & $7(53.9 \%)$ & $4(30.8 \%)$ & \\
\hline \multicolumn{6}{|c|}{ Distant metastases $(n=39)$} & 0.000 \\
\hline No & $29(74.4 \%)$ & $3(10.3 \%)$ & $11(37.9 \%)$ & $13(44.8 \%)$ & $2(7.0 \%)$ & \\
\hline Yes & $10(25.6 \%)$ & $0(0.0 \%)$ & $0(0.0 \%)$ & $5(50.0 \%)$ & $5(50.0 \%)$ & \\
\hline
\end{tabular}

TABLE 2

\section{RELATIONSHIP BETWEEN EGFR EXPRESSION AND NECROSIS IN MALIGNANT CANINE MAMMARY TUMOURS}

\begin{tabular}{lccccccc} 
& \multicolumn{5}{c}{$\begin{array}{c}\text { Number (and \%) of tumours showing EGFR } \\
\text { immunostaining in the stated percentage of cells }\end{array}$} & p value \\
\hline & Negative & $<25 \%$ & $25-50 \%$ & $50-75 \%$ & $>75 \%$ & \\
Necrosis $(\mathrm{n}=38)$ & & & & & & 0.002 \\
No & $9(23.7 \%)$ & $3(33.3 \%)$ & $1(11.1 \%)$ & $4(44.5 \%)$ & $1(11.1 \%)$ & $0(0.0 \%)$ & \\
Yes & $29(76.3 \%)$ & $1(3.4 \%)$ & $1(3.4 \%)$ & $10(34.5 \%)$ & $14(48.3 \%)$ & $3(10.3 \%)$ & \\
\hline
\end{tabular}

in CMT-U27 MUC1 knock-down cells when compared to control cells (Fig.6A). There was a corresponding decrease in the protein level of galectin-3 in MUC1 knock-down cells compared to control cells (Fig. 6B). These results demonstrate that MUC1 is involved in galectin-3 regulation in CMMT.

The in vitro demonstration that MUC1 knock-down decreases galectin-3 expression, does not explain their respective expressions in the cell subpopulations in vivo. As a matter of fact, in most primary tumour cells, expression is increased for MUC1 and decreased for galectin-3 whereas in those cells constituting tumour emboli or having aggressive characteristics they are both overexpressed. We thus hypothesized that in CMMT varying levels of galectin-3 expression could in turn play a regulatory effect on MUC1 expression. In order to verify this, we silenced galectin-3, by shRNA, in the CMT-U27 metastatic cell line. Upon galectin-3 knock-down there was a striking circa 5 fold increase in expression of MUC1 mRNA when compared to control cells infected with non-silencing shRNA (Fig. 6C). A corresponding increase in MUC1 protein expression was observed in galectin-3 knock-down cells when compared to control ones (Fig. 6B). Altogether, these results indicate that downregulation of galectin-3 is involved in the up-regulation of MUC1 expression and suggest that MUC1 and galectin-3 are part of a feedback regulatory loop in CMMT.

\section{Sialylation acts as a switch on/switch off mechanism modifying galectin-3 binding to its ligands during tumour progression in CMMT}

Both galectin-3 and its binding-sites can be either down- (primary tumours) or up-regulated (intravascular tumour cells) according to specific settings in CMMT (de Oliveira et al., 2010). Sialylation, particularly $\alpha 2,6$-linkage, is a common posttranslational modification known to negatively affect galectin-3 recognition and binding to its $\beta$-galactoside ligands (de Melo et al., 2007). Hence, we hypothesized that, in CMMT, galectin-3 binding to its ligands might be intermittently impaired by sialylation. In order to assess this, we verified the binding of a galectin-3/alkaline phosphatase (Gal3/AP) probe in 10 CMMT cases with or without neuraminidase treatment, prior to incubation. In the absence of treatment, the majority of tumour cells presented low galectin-3 binding site expression, with few exceptions among which the invasive front of CMMT (Fig. 7A). However, interestingly, following neuraminidase treatment of CMMT sections, binding of Gal3/AP probe to the neoplastic tissues was greatly increased and widespread (Fig. 7B,C).

Next, in order to further substantiate our hypothesis the reactivity of two plant lectins, Sambucus Nigra Agglutinin (SNA), which
A

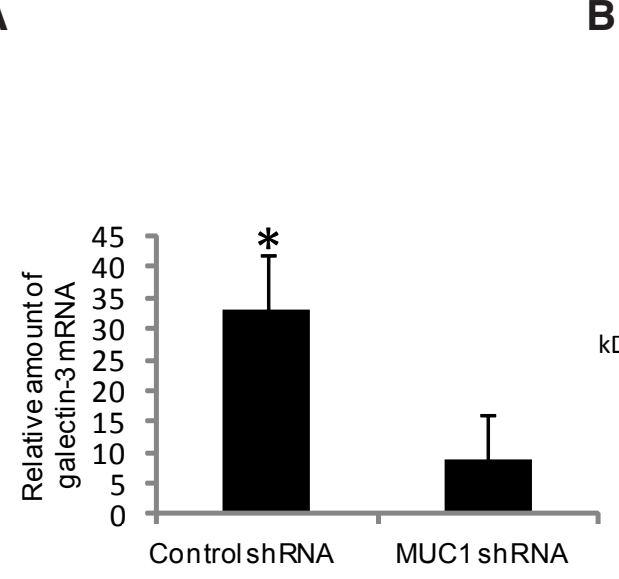

B

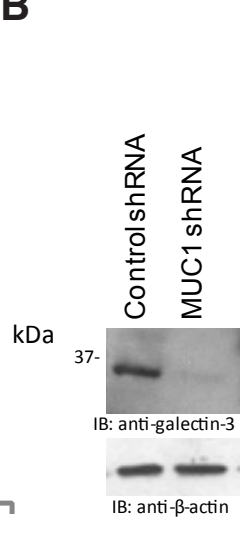

C
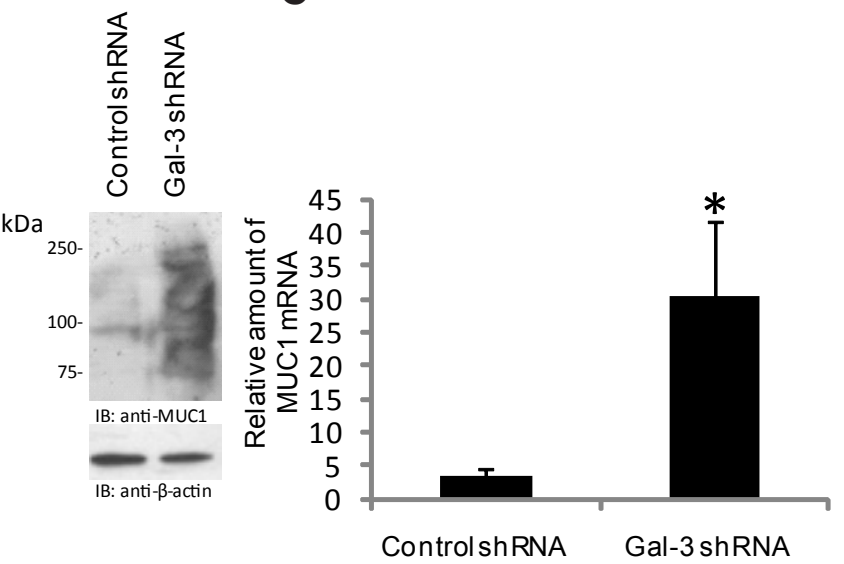

Fig. 6. Galectin-3 and MUC1 function in a regulatory loop in the metastatic CMT-U27 cell line. (A) Data from real-time PCR for galectin-3 using RNA from CMT-U27 cells either uninhibited or inhibited for MUC1 using short hairpin RNA shows that levels of galectin-3 mRNA were decreased upon MUC1 knockdown. Cells infected with scrambled oligos were used as a control. Asterisks indicate significant differences (p<0.05) by Student's t-test. cDNA contents were normalized on the basis of predetermined levels of $18 S$. The results represent the mean $\pm S D$ of triplicate samples in one of three similar experiments. (B) Western blot study of the expression of MUC1 and galectin-3 upon knock-down. (C) Data from real-time PCR for MUC1 using RNA from CMT-U27 cells either uninhibited or inhibited for galectin-3 using short hairpin RNA; levels of MUC1 mRNA were increased to around 10 fold upon galectin-3 knockdown. Cells infected with scrambled oligos were used as a control. Asterisks indicate significant differences ( $p<0.05)$ by Student's t-test. cDNA contents were normalized on the basis of predetermined levels of $18 S$. The results represent the mean $\pm S D$ of triplicate samples in one of three similar experiments. 
recognizes $\alpha 2,6$ - linked sialic acid, and Maackia Amurensis Lectin (MAL), which recognizes $\alpha 2,3-$ linked sialic acid, was analyzed in the tumours, in parallel with that of Gal3/AP probe. Galectin-3-binding site expression was observed (Fig. 7D) in MAL-binding site positive areas (Fig. 7E) and was virtually independent of the neuraminidase treatment of the sections (Fig. 7F). In contrast, galectin-3-binding site expression was frequently absent (Fig. 7G) from SNA-binding site positive areas (Fig. $7 \mathrm{H}$ ) prior to neuraminidase treatment, following which, increased Gal3/AP binding was observed (Figure 7I). These findings suggest that differential presence of $\alpha 2,6$ - linked sialic acid in sedentary tumour cells and certain tumour subpopulations may account for differences observed in galectin-3-binding site expression and hence undermine galectin-3-mediated adhesion between tumour cells at these locations.

\section{CMT-U27 xenografts in nude mice display a heterogeneous galectin-3-binding site expression pattern, resembling that of CMMT}

The CMT-U27 highly metastatic cell line shows homogeneous expression of galectin-3-binding sites in vitro (de Oliveira et al., 2010). Considering the heterogeneous pattern observed in vivo in CMMT, we aimed to investigate whether the homogeneous pattern observed in the CMT-U27 cell line would undergo microenvironment- associated variations. We thus proceeded by injecting the cell line into the mammary fat pad of female nude mice. Interestingly, the xenografted tumours, presented a distinct pattern of Gal3/AP binding according to the location of the tumour cells. Galectin-3-binding site expression was low in the vast majority of sedentary tumour cells. On the other hand, at the invasive front of the primary tumours, this expression was high as previously seen in CMMT (Fig. 7J). In addition, binding of the Gal3/AP probe was again highly increased, following neuraminidase treatment of areas initially presenting lower levels of galectin-3-binding sites, resembling our observations in CMMT (Fig. 7K,L).

Accordingly, while MAL-binding site expression was low (Fig. 7M), high SNA-binding site expression was observed in sedentary cells (Fig. $7 \mathrm{~N}$ ). Neuraminidase treatment abrogated SNA binding to the tissues (Fig. 70).

Altogether, these results suggest that the microenvironment may play a role in the sialylation-related availability of ligands for galectin-3-binding in CMMT.

\section{T antigen and galectin-3 are co-expressed and interact during vessel invasion in CMMT}

Several effects of galectin-3 interaction with MUC1, crucial in the metastatic process, are dependent on the lectin's binding to the T antigen carried by the mucin (Zhao et al., 2009;

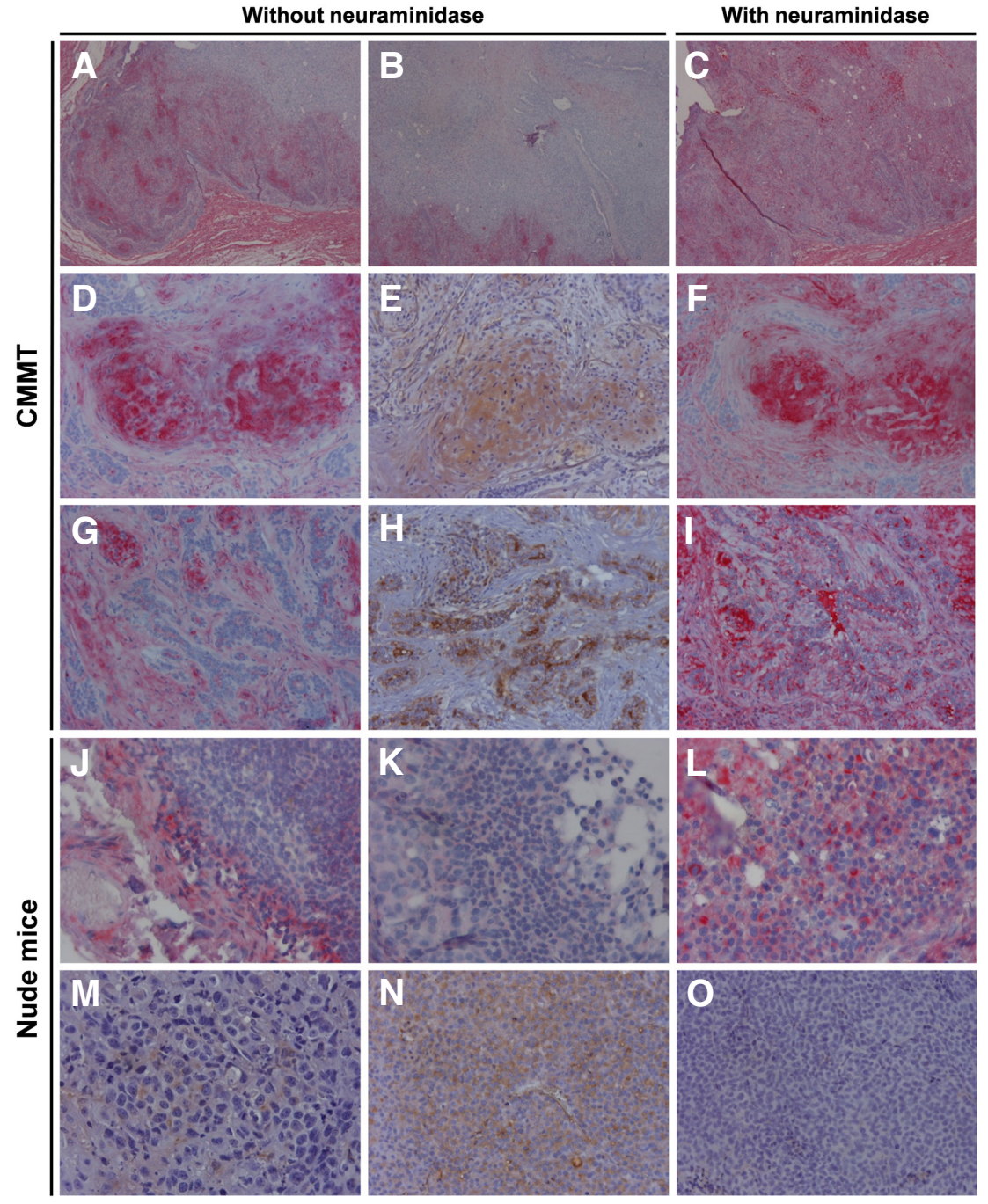

Zhao et al., 2010). Hence, we set out to compare the expression levels of T antigen and its sialylated form in 13 cases with vessel invasion. Most cells of primary CMMT showed higher levels of sialylated T antigen when compared to the un-substituted form of the antigen which was expressed in low levels and was even often negative (Fig. 8A). However, surprisingly, intravascular tumour cells expressed mainly

Fig. 7. Sialylation acts as a switch on/switch off mechanism modifying galectin-3 binding to its ligands during progression in CMMT. Incubation of the CMMT tissues with Gal3/AP was performed with or without prior neuraminidase treatment. High levels of galectin-3 binding sites were consistently observed in the invasive front of the primary tumours (A) (x200 magnification); however the majority of sedentary CMMT cells presented low levels of binding of Ga/3/AP (B) (x200 magnification) which was increased following neuraminidase treatment in the CMMT sections (C) (x200 magnification). Galectin-3-binding site expression was observed (D) (x400 magnification) in positive MAL-binding sites areas (E) (x400 magnification) regardless of neuraminidase treatment(F) (x400 magnification). On the other hand, galectin-3-binding site expression was consistently decreased (G) (x400 magnification) in positive SNA-binding sites areas $\mathbf{( H )}$ (x400 magnification) but increased following neuraminidase treatment (I) (x400 magnification). Accordingly, xenografted tumours showed galectin-3-binding site expression also in the invasive front; (J) (x400 magnification), despite mostareas of the tumours presented decreased expression of galectin-3-binding sites (K) (x630 magnification) which was again increased following neuraminidase treatment (L) (x630 magnification). Xenografted tumours present low levels of MAL-binding site expression (M) (x630 magnification) when compared to SNA-binding site expression (N) (x630 magnification), neuraminidase treatment abrogated SNA-binding to the xenografted tumours (0) (x630 magnification). 

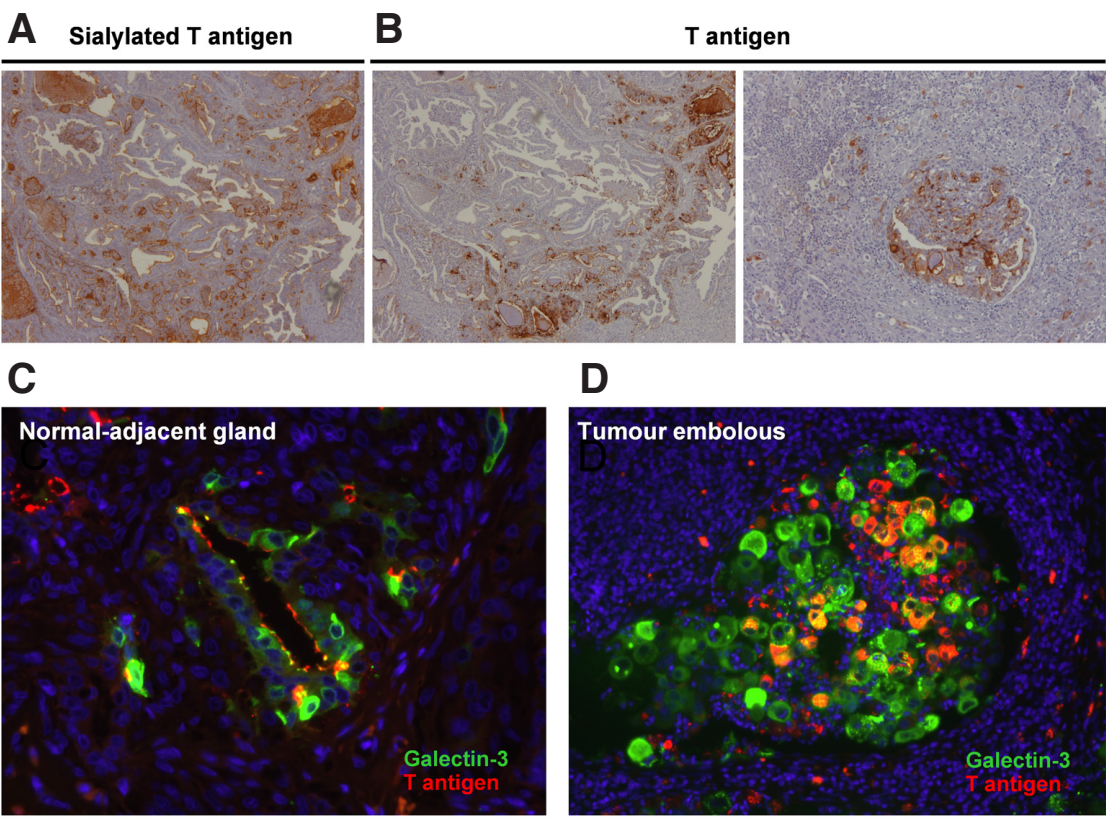

\section{D}
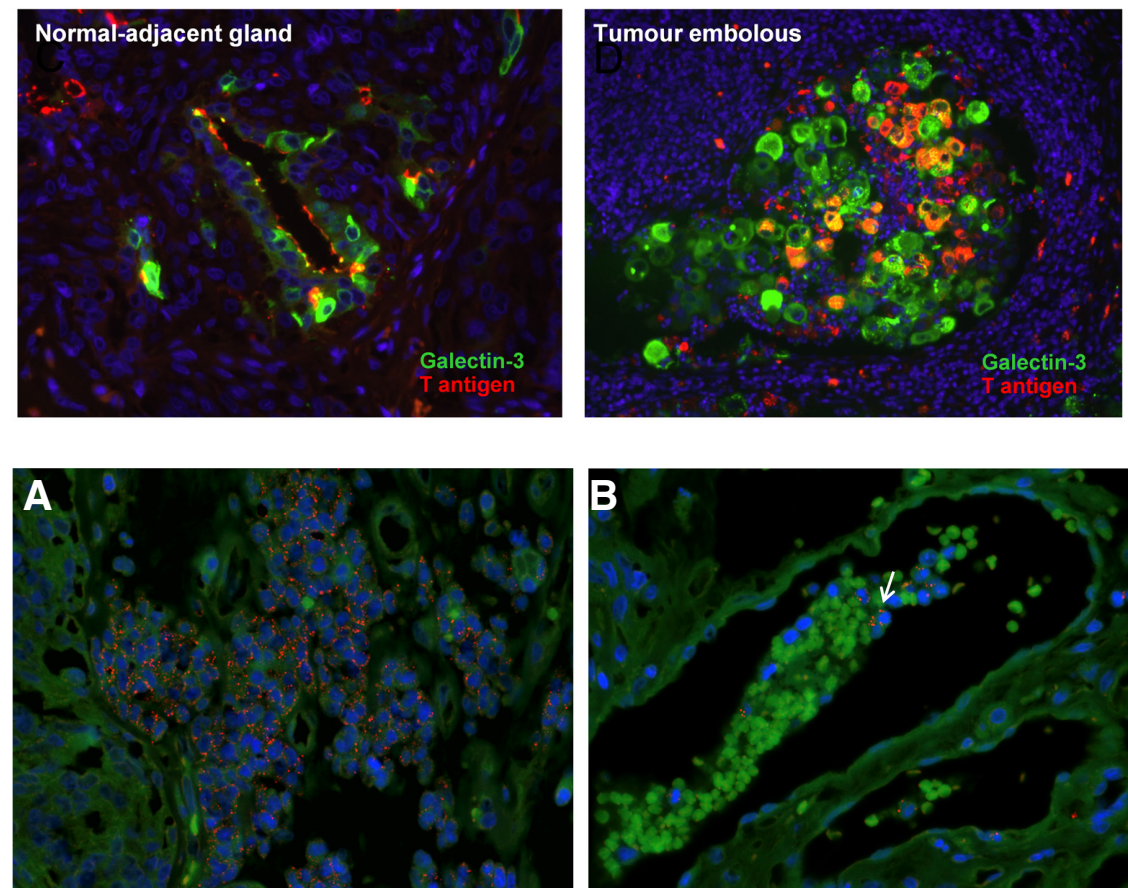

Fig. 8 (Left). Despite sedentary cell expression of increased levels of sialylated T antigen, intravascular tumour cells present co-localization between galectin-3 and the un-sialylated for of the antigen in CMMT. Photomicrographs depictT antigen and sialylatedT antigen immunostaining (brown colour) with haematoxylin counterstain in CMMT. Most cells of CMMT, presented high levels of sialylated $T$ antigen revealed by neuraminidase treatment (A) (x200 magnification) when compared to the $T$ antigen (B) (x200 magnification). Surprisingly, intravascular tumour cells expressed the unsialylated form of the antigen (B) (x400 magnification). Co-localization was assessed by double-labelling immunofluorescence using anti-T antigen and galectin-3 antibodies (C) normal glands within primary tumours expressed T antigen only in the apical surface of the cells and despite galectin-3 was also expressed by this cells they did not co-localize (D) however, co-localization of galectin-3 with $T$ antigen was interestingly observed in vessel-invading cells. Photomicrograph magnifications 400x.

Fig. 9 (Left). Intravascular tumour cells show interaction between galectin-3 and the un-sialylated form of the T antigen in CMMT in vivo. Interaction was assessed by proximity ligation assay using anti-T antigen and galectin-3 antibodies. (A) Although virtually no PLA signals were observed in sedentary cells of primary CMMT, they were abundantly observed in a few cells surrounding vessels showing interaction between Tantigen and galectin-3. (B) Moreover, PLA signals were also consistently observed in intravascular tumour cells particularly at the cell membrane showing interaction between the $T$ antigen and galectin-3 at these locations (arrow). Photomicrograph magnifications 400x. the $\mathrm{T}$ antigen (Fig. 8B). Next, double-labelling studies between galectin-3 and this glycan were performed in the same cases. A few normal mammary glands adjacent to primary tumours which also expressed galectin-3 showed T antigen expression restricted to the apical surface of the cells. Nevertheless, co-expression of the two was never observed (Fig. 8C). However, in vessel-invading cells galectin-3 and the T antigen were co-expressed (Fig. 8D).

In order to prove the interactions between galectin-3 and the $T$ antigen in circulating cells in vivo we used the proximity ligation assay, PLA, which is capable of detecting single events such as protein interactions. Assessment of galectin-3 interaction with the T antigen in the primary tumours, showed virtually no PLA signals. However in the vicinity of vessels (Fig. 9A) and in vessel-invading cells, signal presence was elevated (Fig. 9B). Our data shows the loss of T antigen's sialic acid capping in vessel invasion in CMMT. This allows an important interaction between galectin-3 and $\mathrm{T}$ antigen, and therefore emphasizes a combined role in metastasis.

\section{Discussion}

Metastasis is highly dependent on the ability of tumour cells to evade from primary sites, and to enter and survive in the circulation (Chambers et al., 2002). It is well-known that structural modifications in glycans of glycoproteins can alter their interaction with endogenous lectins, modulating their role in cell adhesion and signal transduction (Ohtsubo et al., 2006). In an earlier study, we have established that the Gal $\beta 1-3 \mathrm{GalNac}$-binding lectin, galectin-3, and its binding-sites are implicated in the metastatic process of mammary tumours (de Oliveira et al., 2010). Specifically, we have demonstrated that i) overall galectin-3 expression is down-regulated in primary CMMT but up-regulated in its intravascular tumour emboli and that ii) both intravasated tumour cells and tumour endothelium overexpress galectin-3-binding sites while in the primary CMMT, on average, there is a decrease of their expression.

For the present study, our specific goal was to gain more insight in the mechanisms by which galectin-3 along with its ligands could be acting in tumour progression and invasion of CMMT.

Among several well-known galectin-3-ligands EGFR and MUC1 are two of the most closely associated to breast cancer (Klijn et al., 1992; Kufe, 2009). In the present study, we observed a clear cellular sub-compartmentalization of MUC1 (apical) and EGFR (basal) membrane staining in normal-adjacent mammary glands. On the other hand, in CMMT neoplastic cells, MUC1 and EGFR were expressed in a predominantly vesicular and cytoplasmic pattern and scattered throughout the entire membrane. Nevertheless, in intravascular cells of CMMT they were often expressed focally at the cell membrane. Interestingly at these locations the proteins were co-expressed with galectin-3. In normal mammary tissues MUC1 is localized at the apical while EGFR is present at the basolateral side (Kufe, 2009; Klijn et al., 1992) of cell membranes and therefore 
there is virtually no interaction between them. Their interaction in a non-tumour context is a sign of temporary polarization disruption and hence appears to mediate cell survival programs (Kufe, 2009). Recent studies in the human and experimental animal models have indicated that in several types of carcinoma there is a permanent loss of polarization leading to constant interaction of transmembrane mucins and growth factor receptors (Kufe, 2009). Our data on galectin-3 ligands' expression in CMMT support this assumption. Moreover, in our study, EGFR expression was significantly associated to the presence of necrosis in CMMT. In accordance, in a previous work, EGFR expression was thoroughly studied by ligand binding in a series of canine normal mammary tissue, benign and malignant tumours and although no statistical differences were found between the levels of expression of the receptor between non-tumorous tissues and CMMT (Rutteman et al., 1994), when analysing EGFR by autoradiography, a high level of activity in necrotic areas was found (Berns and Rutteman, unpublished data). Similarly, increased galectin-3 expression around necrotic (hypoxic) areas has also been reported in CMT (de Oliveira et al., 2010) and in human cancer (Neder et al., 2004). Adding that to the fact that vessel-invading tumour cells express both galectin-3 and EGFR, the hypothesis of a passive mechanism of invasion wherein tumour cells which intravasate, are mainly those exposed to stress conditions (e.g. hypoxia which also leads to activation of EGFR kinase and may enhance cell migration in cancer cells) (Bockhorn et al., 2007; Wang and Schneider, 2010), seems very plausible in CMMT. Recently, interactions between MUC1 and EGFR were suggested to be facilitated by galectin-3, since it bridges them in vitro by recognizing and binding glycans on both proteins in breast cancer cells (Ramasamy et al., 2007). This study corroborates the hypothesis that depolarized cancer cells are able to use MUC1-EGFR interactions as a sustained survival signalling loop (Kufe, 2009). Our data further suggest that galectin-3-mediated MUC1-EGFR interactions might play a role in the metastatic process in vivo as indicated by co-expression of the proteins with galectin-3 in vessel-invading cells, corroborated by the precipitation studies.

In accordance with the literature and data recently reported by our group (de Oliveira JT et al., 2009), in the present work, high expression of MUC1 was significantly associated to vascular invasion and metastases occurrence in CMMT. Interestingly, MUC1 overexpression in primary CMMT was also significantly associated to down-regulation of galectin-3. Down-regulation of galectin-3 in several types of human and canine cancer appears to be related to tumour progression (Castronovo et al., 1996; Ahmed et al., 2007; de Oliveira et al., 2010). Loss of this protein has been reported to impair cell-cell cohesion allowing increased tumour cell motility (Liu and Rabinovich, 2005). MUC1 mucin on its hand acts as an anti-adhesive molecule in cancer cells due to both its large size and sialic acid-conferred negative repulsive charges (Jonckheere, 2008). Our data in vivo show a concomitant up-regulation of galectin-3 and MUC1 in vessel invading cells. Other authors have reported in mice xenografts of breast cancer cell lines that increased presence of galectin-3 seems to favour cell-adhesion and consequently provide survival advantage to blood-borne tumour cells, by clustering MUC1 at the cell membrane, (Zhao et al., 2010). The reasons why galectin-3 expression varies in cancer cells according to their location are still poorly understood.

In cancer, down-regulation of galectin-3 has been associated to methylation of its promoter (Ahmed etal., 2007) and altered expression of transcription factors involved in its regulation, such as the RUNX family (Vladimirova etal., 2008). Irrespective of other possible existing mechanisms, in the present study we have demonstrated - to the best of our knowledge, for the first time - that a decrease of galectin-3 plays a role in MUC1 up-regulation, in mammary cancer, suggestive of an indirect contribution to de-adhesion and in accordance to our in vivo observations. So far, the only existing study showing a role for galectin -3 in MUC1's regulation was that of Merlin et al.,2011) in which galectin-3 knock-down, in a pancreatic cancer cell line, led to a decrease in MUC1 expression in accordance with their in vivo data from human pancreatic carcinoma where both galectin-3 and MUC1 are overexpressed in primary tumours. Furthermore, our data showing that MUC1 knock-down leads to decreased levels of galectin-3 imply that MUC-1 in turn is able to up-regulate galectin-3. This is in accordance with a recent report showing that MUC1 stabilizes galectin-3 mRNA in breast cancer cells through an $\mathrm{N}$-glycosylation dependent mechanism whereby extracellular MUC1 C-terminal domain (MUC1-C) suppresses the expression of a galectin-3-transcript de-stabilizing microRNA (Ramasamy et al., 2007). The fact that galectin-3, on its hand, binds to the MUC1-C N-glycan involved in its own regulation suggests that changes in glycosylation could account for differences in the lectin's regulation by MUC1 according to different cellular contexts.

Sialylation a type of glycosylation prevalent in cancer, has long been suggested to be involved in cellular differentiation and migration through cyclical masking/unmasking of galectin-binding sites (Gillespie et al., 1993). Another key finding of the current study was that galectin-3 ability to bind to its ligands was impaired by sialylation in most areas of primary CMMT. Vessel-invading and cells of invasive fronts in CMMT were notable exceptions to this impaired expression of galectin-3-binding sites. A report of Holíková et al., (2002), demonstrated that $\alpha 2,6$ - but not $\alpha 2,3$-linked N-acetyl-D-neuraminic acid is implicated in masking galectin-3 binding sites in squamous epithelial carcinomas. Hence, in parallel to the use of the Gal3/AP probe, before and after neuraminidase treatment, we assessed the reactivity profile of two plant lectins which recognize distinct types

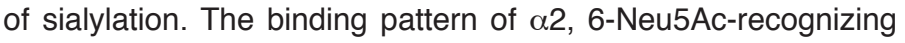
plant lectin (i.e. SNA) was inversely associated to Gal3/AP ability to bind to the CMMT tissues. In contrast to $\alpha 2,6-$, expression of $\alpha 2,3-$ linked sialic acid, assessed with MAL, was not associated to galectin-3 binding site negative areas. Several reports have shown that while only occasionally binding to $\alpha 2,6$-sialylated glycans, galectin-3 binds well to $\alpha 2$, 3-sialylated glycans (Hirabayashi et al., 2002; de Melo et al., 2007). Thus, the findings of the present study suggest that, although probably not exclusively, $\alpha 2,6$ sialylation can be an on/off switch for galectin-3 binding in situ.

The reasons why invading tumour cells consistently showed increased binding of galectin-3 remain to be determined. However, whatever reasons may exist they must be microenvironment-related as suggested by the fact that CMT-U27 cells acquire heterogeneous expression of galectin-3-binding sites upon being xenografted in nude mice, while these sites' expression is homogeneous during in vitro culture (de Oliveira et al., 2010). This being so, at least two explanations are plausible and reflect existing pathophysiological mechanisms 1) cells expressing unmasked galectin-3 ligands have invasion advantage and 2) mainly applicable to vessel-invading cells and cells in vessel surroundings, sialidases of serum and immune cell origin can cleave the $\alpha$-bound sialic acid from 


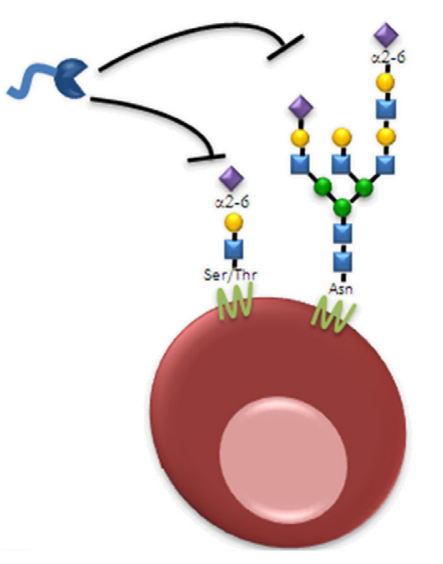

Primary tumour cells

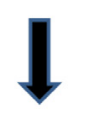

De adhesion

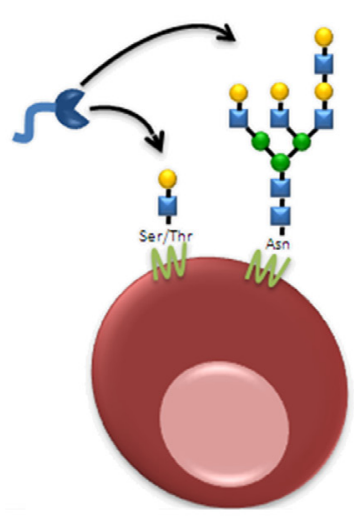

Intravascular tumour cells

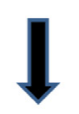

Increased homo and heterotypic adhesion

Galectin-3

Fig. 10. Proposed model suggesting that microenvironment alterations may modify sialylation of galectin-3-ligands at the cell surface, masking terminal galactose saccharides and thereby cyclically altering galectin-3-mediated adhesion/de-adhesion in cancer cells.

galectin-3-ligands. The first explanation is based on the fact that several factors which could alone or in conjunction contribute to increased expression of unmasked galectin-3-ligands in invading cells have been related to migration and invasive capacity: (a) there is higher activity in invading cells of glycosyltranferases responsible for assembling ligands for this lectin, such as the metastasis-related Mgat5, with concomitant lower activity of competitive GnTIII, which leads to the production of $\mathrm{N}$-glycans not recognized by galectin-3 (Nangia-Makker et al., 2000; Pinho et al., 2009b); (b) there is down-regulation of sialyltransferases which would otherwise mask galectin-3-ligands in these cells. Up or down-regulating of sialyltransferases is a well-known mechanism of motility tuning, turning galectin3-binding positive cells into negative ones and vice-versa, allowing cells to migrate in a physiological context (Gillespie et al., 1993). Furthermore, in normal lactating mammary glands sialyltransferase ST6Gall expression is increased (Dalziel et al., 2001) while galectin-3 is down-regulated (Mengwasser et al., 2002). The second explanation is supported by indications that there is increased sialidase activity in metastatic cells, and that sialidases are responsible for low levels of sialic acid in highly metastatic colon cells when compared to cells with low metastatic potential (Miyagi et al., 2008). Also, increased tissue and serum sialidase levels have been observed in human breast cancer (Sönmez et al., 1999). Moreover, macrophages, as well as other peri- and intravascular immune cells are able to secrete lysosomal sialidases and could therefore be co-responsible for decreased sialic acid capping of galectin-3-ligands in this context (Miyagi et al., 2008).

Concerning the specific microenvironment of blood-borne tumour cells, several studies have demonstrated that galectin-3 interacts with MUC1 by binding the T antigen (Yu et al., 2007). Neverthless its sialylated form, is one of the dominant glycoforms of MUC1 in breast cancer patients (Storr et al., 2008). For this reason, we assessed and compared the expression of the T antigen and its sialylated form in CMMT. Our data showed an increased expression of sialylated $T$ antigen in most sedentary tumour cells as compared to the un-substituted form of the antigen. Accordingly, sialylation of the $T$ antigen has been reported to play an important role in promoting early stages of oncogenesis (Picco et al., 2010). Interestingly, however, vessel-invading cells presented an increased $\mathrm{T}$ antigen expression. In corroboration of our data, $T$ antigen enrichment has been recently proven to be very useful in assessing circulating tumour cells (Schindlbeck et al., 2008). Moreover, interaction of the $T$ antigen and galectin-3 was observed by PLA in vessel-invading cells but not in sedentary cells in CMMT. The galectin-3-MUC1 interaction via T antigen has been shown to induce MUC1 cell surface polarization and exposure of the cell surface adhesion molecules thereby enhancing tumour cell homotypic aggregation and preventing anoikis in vitro and in in vivo experimental models (Yu et al., 2007; Zhao et al., 2010). However, until now, strong evidence in a spontaneous model of mammary carcinogenesis was lacking to support its relevance.

Our understanding of the initial steps of the metastatic process is still very limited and as such, the use of a spontaneously occurring animal model in which these events precipitate much faster than in humans is of great interest (Paoloni and Khanna, 2008). In conclusion, based on the results here presented and those of others, we suggest that in CMMT, down-regulation of galectin-3 in cancer cells can lead to MUC1 overexpression, while MUC1 decrease could lower galectin-3 expression, as part of a dynamic glycosylation-dependent regulatory loop. We hypothesize that differential glycosylation of the mucin, in specific tumour microenvironment scenarios, might account for the apparently contradictory role played by these proteins in each other's regulation, in CMMT. Further studies are needed in order to confirm this hypothesis. Moreover, our study provides new insight to the posttranslational sialic-acid dependent masking mechanisms that modulate the exposure of terminal galactose saccharides at the cell surface and thus cyclically alter galectin-3-mediated adhesion/de-adhesion capacity in different cancer cell subpopulations (Fig. 10). Future studies are warranted in order to completely uncover the role of microenvironment stimuli in differential/dynamic expression of galectin-3 and its ligands in CMMT.

\section{Materials and Methods}

\section{Animal tissues}

Malignant mammary tumour specimens were obtained from 40 female dogs at surgery or at post-mortem rapidly following euthanasia, in the years $2002-2006$. Tumours stemmed from dogs of various pure and mixed breeds, and were randomly selected from the files of the veterinary pathology laboratory of the Instituto de Ciências Biomédicas Abel SalazarUniversity of Porto. Tissues had been fixed in $10 \%$ neutral buffered formalin 
and embedded in paraffin. Serial sections $3 \mu \mathrm{m}$ thick were cut from each block. One section was stained with haematoxylin and eosin (HE) and the other sections were used for immunohistochemical studies. Follow up was performed in all operated animals for up to two years as described (de Matos et al., 2006).

\section{Histochemistry}

Expression of MUC1, EGFR and galectin-3 was evaluated in the formalinfixed, paraffin-embedded sections of spontaneously occurring CMMT, using standard immunohistochemistry protocols. Briefly, $4 \mu \mathrm{m}$ thick paraffin sections were deparaffinised, then hydrated, and endogenous peroxidase was blocked with $\mathrm{H}_{2} \mathrm{O}_{2}$. After blocking with the appropriate normal sera, sections were incubated with 1:10 rat anti-galectin-3 monoclonal antibody (M3/38) and 1:150 rabbit polyclonal anti-galectin 3 (Abcam); 1:50 goat antiMUC1 polyclonal antibody (Santa Cruz Biotechnology, directed against the $\mathrm{C}$-terminal domain and hence recognizing the protein independently from its glycosylation), and 1:50 rabbit anti-EGFR polyclonal antibody (Santa Cruz Biotechnology) for $1 \mathrm{~h}$ at room temperature and overnight respectively, followed by 1:200 donkey anti - rat (Jacksonlmmuno Research) and 1:200 donkey anti-goat (Santa Cruz Biotechnology) and donkey anti-rabbit peroxidase-conjugated secondary antibodies, respectively. For T antigen and sialylated $T$ antigen assessment, slides were incubated overnight with 1:50 Mab 3C9 (kindly provided by Prof. Henrik Clausen from Copenhagen, Denmark), without or with previous neuraminidase treatment for 2 hours at $37^{\circ} \mathrm{C}$ respectively. Sialylation type profile was assessed using two biotinylated plant lectins, SNA (Vector), which recognizes $\alpha 2$, 6- linked sialic acid and MAL (Vector), which recognizes $\alpha 2$, 3- linked sialic acid, incubated for 1 hour at room temperature in a 1:250 dilution followed by incubation of avidin-biotin system (Vector) for $45 \mathrm{~min}$ at room temperature. Peroxidase activity was examined using diaminobenzidine tetrahydroxychloride solution (DAB, Dako) as the substrate. Sections were counterstained with haematoxylin. Negative controls in which the primary antibody was replaced by BSA $5 \%$ in phosphate buggered saline (PBS) were performed in all series and sections of human gastric carcinomas were used as positive controls.

Galectin-3-binding sites were detected both in spontaneously occurring CMMT and malignant CMT-U27 xenografts using a Gal3/AP probe (de Melo et al., 2007) in the same sections as previously described, without or with previous neuraminidase treatment (cleaving both $\alpha 2,6$ and $\alpha 2,3$ bound sialic acids). Neuraminidase treatment was carried out for $2 \mathrm{~h}$ at $37^{\circ} \mathrm{C}$ at a final concentration of $0.1 \mathrm{U} / \mathrm{mL}$ (de Oliveira et al., 2010). Alkaline phosphatase activity was observed using Fast Red (Dako). Sections were counterstained with haematoxylin. As a negative control, an assay using lactose to inhibit the carbohydrate recognition domain (CRD) of galectin-3 was performed.

\section{Scoring of immunostaining and statistical analysis}

Assessment of markers expression in CMMT was based on a semiquantitative analysis and tumours were grouped, according to the percentage of immunoreactive cells throughout the whole lesion, in: $<10 \%$, which was considered negative; $<25 \% ; 25-50 \% ; 50-75 \% ;>75 \%$. Initially a descriptive study of the data was performed. Then association hypotheses were tested, using the Student $t$ test for continuous variables and Fisher's exact test or Chi-square test for discrete variables. SPSS software (version 13.0) (SPSS, Chicago, IL, USA) was used for statistical analysis.

\section{Double-labelling Immunofluorescence}

For simultaneous visualization of galectin-3 with MUC1, T antigen and EGFR on the same tissue section, double-label immunofluorescence was performed. Representative tissue sections were chosen with high and low expression of each antigen and sections with the same percentage of positive cells for the antigens. Briefly, after blocking with $10 \%$ diluted normal sera for $20 \mathrm{~min}$, sections were incubated with the first primary antibodies rabbit anti-galectin-3 1:150 in 5\% bovine serum albumin (BSA) and anti-MUC1 $1: 50$ overnight at $4^{\circ} \mathrm{C}$, they were then washed in PBS and incubated with Alexa588-conjugated donkey anti-rat antibody (1:200) and biotinylated anti-goat secondary antibody the latter followed by Alexa594-congugated streptavidin incubation for $30 \mathrm{~min}$. Sections were then washed and incubated with $10 \%$ donkey and swine serum for $20 \mathrm{~min}$ to which incubation with second primary antibodies anti-MUC1, anti-EGFR, 3C9 anti- T antigen and anti-galectin-3 respectively, followed overnight at $4^{\circ} \mathrm{C}$. After washing, sections were incubated with biotin-conjugated secondary antibodies (Dako) for $30 \mathrm{~min}$, to which Alexa594-conjugated streptavidin incubation for $30 \mathrm{~min}$ followed for MUC1, EGFR and T antigen and Alexa588-conjugated goat anti-rabbit antibody (1:200, Invitrogen) for galectin-3. All sections were then incubated with 1:100 PBS diluted 4'-6-Diamidino-2-phenylindole (DAPI) for $15 \mathrm{~min}$. Finally slides were mounted in glycerol-based Vectashield medium (Vector, Burlingame, CA). Slides were analysed with a Leica DMIRE2 fluorescent microscope.

\section{Cell lines and culture conditions}

In this study we used a highly metastatic CMMT cell line, CMT-U27, kindly provided by Professor Eva Hellmen from Sweden. The cell line was cultured at $37^{\circ} \mathrm{C}$ in a humidified $5 \% \mathrm{CO} 2$ incubator and maintained in RPMI 1640 medium (with Glutamax and 25 mM Hepes) supplemented with 10\% foetal bovine serum and gentamicin $(50 \mu \mathrm{g} / \mathrm{mL})$.

\section{Experimental nude mice}

Six-seven weeks old female $\mathrm{N}: \mathrm{NIH}(\mathrm{s})$ II-nu/nu mice were inoculated subcutaneously in the mammary fat pad with a suspension of $10^{6}-10^{7}$ cells of CMT-U27 cell line. Mice were periodically observed, weighed and their tumours were measured once a week in three dimensions. Once the xenografted primary tumour attained the volume of $1 \mathrm{~cm}^{3}$ it was excised under general anaesthesia and all efforts were made to minimize suffering. The animals were humanely euthanized whenever their body weight started to decrease or any signs of poor body condition were shown. All studies with experimental animals were approved by the ethics committee of the University of Porto.

\section{RNA interference}

Establishment of galectin-3 knock-down cells was done using a retroviral expression system with short hairpin RNAs (shRNA) (Friedrichs et al., 2007). Briefly, targeting and control vectors were transfected into PhoenixGP packaging cell line and transfected cells were selected using Puromycin (Sigma). For MUC1 knock-down Phoenix cells stably transfected with MUC1 shRNA were also used (kindly offered by Filipe Santos Silva, IPATIMUP, Portugal). Stable transfectants were seeded $\left(1 \times 10^{6}\right.$ cells) and incubated for $24 \mathrm{~h}$ at $32^{\circ} \mathrm{C}$. The virus-containing media were then collected, filtrated through a $0.45 \mu \mathrm{m}$ filter to remove remnant cells, and used to infect target CMT-U27. 6 and 12h post-infection, the media were replaced by selective puromycin-containing media to select infected cells.

\section{RNA extraction and real-time PCR}

Total RNA was isolated from the canine mammary tumour cell lines using TRI Reagent (Sigma) according to manufacturer's instructions. $1 \mu \mathrm{g}$ of RNA were primed with random hexamers and reverse transcribed using Superscript II (Invitrogen) in a final volume of $20 \mu \mathrm{l}$. Two microliters of a 1:10 dilution of this mixture were amplified with SYBR Green (Applied Biosystems) and primers at a final concentration of $300 \mathrm{nM}$ each, in a fluorescence reader ABI Prism 7000, and duplicates were run for each RT product. The level of GAPDH RNA in each sample was measured and used for normalization of target genes abundance. Primer sequences are listed below.

GAL3:

5'CAGGCAGCTTTTCCATTCGA3'/5'ACTGCAACAAATGGGCATCA3'; MUC1:

5'GCACTCGCCATCATCTATGTTC3'/5'CCAGCTGCCCACAGTTCTTT3'; EGFR:

5'GGTCTGGAAGTTTTCGGATGG3'/5'GAGGTTTTGCACAGGCTTCAA3'

\section{Protein extraction, Immunoprecipitation and Western Blot}

Cells were washed twice in PBS, centrifuged at $350 \mathrm{~g}$, re-suspended in lysis buffer (12 mMNa2HPO4, 8 mM NaH2PO4, 0.2\% SDS, 4 mM EDTA, 
0.3 M NaCl, 2\% NP-40, 0.1 M NaF, 50mM Sodium Deoxicolate) with 1 $\mathrm{mM}$ phenylmethylsulfonyl fluoride (PMSF), $1 \mathrm{mM}$ sodium orthovanadate and Complete protease inhibitor cocktail (Roche) and incubated on ice for $15 \mathrm{~min}$. The lysates were then centrifuged, the supernatants collected, and protein content was measured using the bicinchoninic acid method (Pierce), according to the manufacturer's instructions. $500 \mu \mathrm{g}$ of protein extracts were precleared with $50 \mu \mathrm{l}$ of protein G-sepharose beads for 1 , $2 \mathrm{~h}$. After centrifugation, the supernatant was incubated overnight with 1 $\mu \mathrm{l}$ of the polyclonal antibody against galectin- 3 and $5 \mu \mathrm{l}$ of the polyclonal antibodies against MUC1 and EGFR (both from Santa Cruz Biotechnology). After that, incubation with protein G-sepharose was performed, for 4 h. Next, the beads were washed three times with lysis buffer. The immune complexes were released by boiling $5 \mathrm{~min}$ at $95^{\circ} \mathrm{C}$ in Laemmli sampling buffer and the immunoprecipitates along with the total extracts were analysed by standard sodium dodecyl sulphate polyacrylamide gel electrophoresis, SDS-PAGE, (pre-cast 4-20\% tris-glycine gel), transferred to a nitrocellulose membrane (Amersham Biosciences) and blotted with the primary antibodies in 5\% non-fat milk in 1x Tris Buffered Saline with 0.02\% Tween-20 (Sigma). The primary antibodies were revealed using the appropriate peroxidaseconjugated secondary antibodies and the Enhanced Chemiluminescence, $\mathrm{ECL}$, detection kit (BioRad).

\section{In situ PLA}

In situ proximity ligation assay (PLA) (Söderberg et al., 2006) was performed in sections where co-localization for galectin-3/T antigen combinations was observed by immunohistochemistry/double immunofluorescence. Deparaffinised tissue sections were pre-treated according to the immunohistochemistry/immunofluorescence protocol. Then, sections were incubated for $30 \mathrm{~min}$ in PBS with $10 \%$ BSA, to block nonspecific staining. Excess blocking solution was removed and replaced by specific primary antibodies in PBS with $5 \%$ BSA at the optimal dilution. Sections were incubated overnight at $4^{\circ} \mathrm{C}$. The PLA assays were performed using the DuoLink detection kit 613 (Olink AB, Uppsala, Sweden) according to the manufacturer's instructions. After washing, oligonucleotide-conjugated PLAsecondary probes were added in 1:5 dilutions in PBS with 5\% BSA and slides incubated in a pre-heated humid chamber for $1 \mathrm{~h} 45 \mathrm{~min}$ at $37^{\circ} \mathrm{C}$. Briefly, connector oligonucleotides were hybridized to probe pairs for $15 \mathrm{~min}$ and circularized by ligation for $15 \mathrm{~min}$. The sections were incubated with the processive $\phi 29$ DNA polymerase for $90 \mathrm{~min}$ to produce rolling circle products (RCPs). RCPs were visualized with fluorescently labelled oligonucleotides and the sections counterstained with Hoechst 33342. Samples were examined under a Zeiss Imager.Z1 Axio fluorescence microscope equipped with DAPI, fluorescein isothiocyanate 1 (FITC) and Texas Red filters. PLA products are seen as bright fluorescent dots. Images were acquired using a Zeiss Axio cam MRm and the AxioVision Rel. 4.8 software. The resulting images were modified using ImageJ as follows: background with radius 4 was subtracted from the red channel of the RGB images and a maximum filter with radius 1 was applied. The result was intensity-scaled to suit printing demands.

\section{Acknowledgments}

We thank Filipe Santos-Silva for the MUC1 knock-down shorthairpin system, Célia Lopes for all technical support, Sofia Santos for the illustration and Prof. E. Helmén for supplying the CMT-U27 cell line. This work was supported by the Portuguese agency "Fundação para a Ciência e a Tecnologia, Programa Operacional Ciência e Inovação 2010 (POCI 2010) do Quadro Comunitário de Apoio III" and Project Grant no. PIC/IC/82716/2007. JdO (SFRH/ BD/ 44441/2008) and JG (SFRH/BD/40563/2007) acknowledge FCT. IPATIMUP is an Associate Laboratory of the Portuguese Ministry of Ministry of Science, Technology and Higher Education and is partially supported by FCT, the Portuguese Foundation for Science and Technology.

\section{References}

AHMED, H., BANERJEE, P. P., VASTA, G. R. (2007). Differential expression of galectins in normal, benign and malignant prostate epithelial cells: silencing of galectin-3 expression in prostate cancer by its promoter methylation. Biochem Biophys Res Commun 358: 241-246.

BOCKHORN, M., JAIN, R. K., MUNN, L. L. (2007). Active versus passive mechanisms in metastasis: do cancer cells crawl into vessels, or are they pushed? Lancet Oncol 8: 444-448.

BURGESS, A. W., CHO, H. S., EIGENBROT, C., FERGUSON, K. M., GARRETT, T. P., LEAHY, D. J., LEMMON, M. A., SLIWKOWSKI, M. X., WARD, C. W., YOKOYAMA, S. (2003). An open-and-shut case? Recent insights into the activation of EGF/ ErbB receptors. Mol Cell 12: 541-552.

CASTRONOVO, V., VAN DEN BRÛLE, F. A., JACKERS, P., CLAUSSE, N., LIU, F. T. GILLET, C., SOBEL, M. E. (1996). Decreased expression of galectin-3 is associated with progression of human breast cancer. J Pathol 179: 43-48.

CHAMBERS, A. F., GROOM, A. C., MACDONALD, I. C. (2002). Dissemination and growth of cancer cells in metastatic sites. Nat Rev Cancer 2: 563-572.

da COSTA, A., OlIVEIRA, J. T., GÄRTNER, F., KOHN, B., GRUBER, A. D., KLOPFLEISCH, R. (2010). Potential markers for detection of circulating canine mammary tumor cells in the peripheral blood. Vet $J$.

COUTO, J. R., TAYLOR, M. R., GODWIN, S. G., CERIANI, R. L., PETERSON, J. A. (1996). Cloning and sequence analysis of human breast epithelial antigen BA46 reveals an RGD cell adhesion sequence presented on an epidermal growth factor-like domain. DNA Cell Biol 15: 281-286.

DALZIEL, M., HUANG, R.Y., DALL'OLIO, F., MORRIS, JR., TAYLOR-PAPADIMITRIOU, J., LAU, J.T. 2001. Mouse ST6Gal sialyltransferase gene expression during mammary gland lactation. Glycobiology 11: 407-412.

FRIEDRICHS, J., TORKKO, J. M., HELENIUS, J., TERÄVÄINEN, T. P., FÜLLEKRUG, J., MULLER, D. J., SIMONS, K., MANNINEN, A. (2007). Contributions of galectin-3 and -9 to epithelial cell adhesion analyzed by single cell force spectroscopy. $J$ Biol Chem 282: 29375-29383.

GILLESPIE, W., PAULSON, J. C., KELM, S., PANG, M., BAUM, L. G. (1993). Regulation of alpha 2, 3-sialyltransferase expression correlates with conversion of peanut agglutinin (PNA)+ to PNA- phenotype in developing thymocytes. $J$ Biol Chem 268: 3801-3804

HIRABAYASHI, J., HASHIDATE, T., ARATA, Y., NISHI, N., NAKAMURA, T., HIRASHIMA, M., URASHIMA, T., OKA, T., FUTAI, M., MULLER, W. E., YAGI, F., KASAI, K. (2002), Oligosaccharide specificity of galectins: a search by frontal affinity chromatography. Biochim Biophys Acta 1572: 232-254.

HOLÍKOVÁ, Z., HRDLICKOVÁ-CELA, E., PLZÁK, J., SMETANA, K. JR, BETKA, J., DVORÁNKOVÁ, B., ESNER, M., WASANO, K., ANDRÉ, S., KALTNER, H. MOTLÍK, J., HERCOGOVÁ, J., KODET, R., GABIUS, H. J. (2002). Defining the glycophenotype of squamous epithelia using plant and mammalian lectins. Differentiation-dependent expression of alpha2,6- and alpha2,3-linked $\mathrm{N}$-acetylneuraminic acid in squamous epithelia and carcinomas, and its differential effect on binding of the endogenous lectins galectins-1 and -3. APMIS 110: 845-856.

JONCKHEERE, N., VAN, SEUNINGEN, I. (2008). The membrane-bound mucins: how large O-glycoproteins play key roles in epithelial cancers and hold promise as biological tools for gene-based and immunotherapies. Crit Rev Oncog 14:177-196.

KLIJN, J. G., BERNS, P. M., SCHMITZ, P. M., FOEKENS, J. A. (1992).The clinical significance of epidermal growth factor receptor (EGF-R) in human breast cancer: a review on 5232 patients. Endocr Rev 13: 13-17.

KUFE, D. W. (2009). Mucins in cancer: function, prognosis and therapy. Nat Rev Cancer 9: 874-885.

LI, Y., REN, J., YU, W-H., LI, G., KUWAHARA, H., YIN, L., CARRAWAY, K. L. AND KUFE, D. (2001). The EGF receptor regulates interaction of the human DF3/MUC1 carcinoma antigen with c-Src and $\beta$-catenin. J Biol Chem 276: 35239-35242.

LIU, F. T. AND RABINOVICH, G. A. (2005). Galectins as modulators of tumour progression. Nat Rev Cancer 5: 29-41.

MARCOS, N. T., PINHO, S., GRANDELA, C., CRUZ, A., SAMYN-PETIT, B., HARDUIN-LEPERS, A., ALMEIDA, R., SILVA, F., MORAIS, V., COSTA, J., KIHLBERG, J., CLAUSEN, H., REIS, C. A. (2004) Role of the human ST6GalNAc-I and ST6GalNAc-II in the synthesis of the cancer-associated sialyl-Tn antigen. Cancer Res 64: 7050-7057.

MATOS, A. J., LOPES, C., CARVALHEIRA, J., SANTOS, M., RUTTEMAN, G. R., GÄRTNER, F. (2006). E-cadherin expression in canine malignant mammary tumours: relationship to other clinico-pathological variables. J Comp Pathol 134: 182-189.

de MELO, F. H., BUTERA, D., MEDEIROS, R. S., ANDRADE, L. N., NONOGAKI, S., SOARES, F. A., ALVAREZ, R. A., MOURA DA SILVA, A. M., CHAMMAS, R. 
(2007). Biological applications of a chimeric probe for the assessment of galectin-3 ligands. J Histochem Cytochem 55: 1015-1026.

MENGWASSER, J., LIU, F. T., SLEEMAN, J. P. 2002. Galectin-3 is strongly upregulated in nonapoptosing mammary epithelial cells during rat mammary gland involution. Glycobiology 12: 129-134.

MERLIN, J., STECHLY, L., DE BEAUCÉ, S., MONTÉ, D., LETEURTRE, E., VAN SEUNINGEN, I., HUET, G., PIGNY, P. (2011). Galectin-3 regulates MUC1 and EGFR cellular distribution and EGFR downstream pathways in pancreatic cancer cells. Oncogene.

MIYAGI, T., WADA, T., YAMAGUCHI, K., SHIOZAKI, K., SATO, I., KAKUGAWA, Y., YAMANAMI, H., FUJIYA, T. (2008). Human sialidase as a cancer marker. Proteomics 8: 3303-3311.

NANGIA-MAKKER, P., HONJO, Y., SARVIS, R., AKAHANI, S., HOGAN, V., PIENTA K. J., RAZ, A. (2000). Galectin-3 induces endothelial cell morphogenesis and angiogenesis. Am J Pathol 156: 899-909.

NEDER, L., MARIE, S. K., CARLOTTI, C. G. JR., GABBAI, A. A., ROSEMBERG, S., MALHEIROS, S. M., SIQUEIRA, R. P., OBA-SHINJO, S. M., UNO, M., AGUIAR, P. H., MIURA, F., CHAMMAS, R. (2004). Galectin-3 as an immunohistochemical tool to distinguish pilocytic astrocytomas from diffuse astrocytomas, and glioblastomas from anaplastic oligodendrogliomas. Brain Pathol 14: 399-405.

ORR, F. W., WANG, H. H. (2001). Tumor cell interactions with the microvasculature: a rate-limiting step in metastasis. Surg Oncol Clin N Am 10: 357-381.

OHTSUBO, K., MARTH, J. D. (2006). Glycosylation in cellular mechanisms of health and disease. Cell 126(5): 855-867.

de OLIVEIRA, J. T., DE MATOS, A. J. F., GOMES, J., VILANOVA, M., HESPANHOL, V., MANNINEN, A., RUTTEMAN, G., CHAMMAS, R., GÄRTNER, F., BERNARDES, E. S., (2010). Cordinated expression of galectin-3 and Galectins-3-binding sites in malignant mammary tumours: implications for tumour metastasis. Glycobiology 20: 1341-1352.

de OLIVEIRA, J. T., PINHO, S. S., DE MATOS, A. J., HESPANHOL, V., REIS, C. A., GÄRTNER, F. (2009). MUC1 expression in canine malignant mammary tumours and relationship to clinicopathological features. Vet $J$ 182: 491-493.

PAOLONI, M., KHANNA, C. (2008). Translation of new cancer treatments from pet dogs to humans. Nat Rev Cancer 8: 147-156.

PICCO, G., JULIEN, S., BROCKHAUSEN, I., BEATSON, R., ANTONOPOULOS, A. HASLAM, S., MANDEL, U., DELL, A., PINDER, S., TAYLOR-PAPADIMITRIOU, J., BURCHELL, J. (2010). Over-expression of ST3Gal-I promotes mammary tumourigenesis. Glycobiology 20: 1241-1250.

PINHO, S. S., REIS, C. A., PAREDES, J., MAGALHÃES, A. M., FERREIRA, A. C., FIGUEIREDO, J., XIAOGANG, W., CARNEIRO, F., GÄRTNER, F., SERUCA, R. (2009). The role of $\mathrm{N}$-acetylglucosaminyltransferase III and $\mathrm{V}$ in the posttranscriptional modifications of E-cadherin. Hum Mol Genet 18: 2599-2608. (a)

PINHO, S. S., OSÓRIO, H., NITA-LAZAR, M., GOMES, J., LOPES, C., GÄRTNER, F., REIS, C. A. (2009). Role of E-cadherin N-glycosylation profile in a mammary tumor model. Biochem Biophys Res Commun 379: 1091-1096. (b)

POWELL, L. D., WHITEHEART, S. W., HART, G. W. (1987). Cell surface sialic acid influences tumor cell recognition in the mixed lymphocyte reaction. $J$ Immunol 139: $262-270$

RAMASAMY, S., DURAISAMY, S., BARBASHOV, S., KAWANO, T., KHARBANDA, S., KUFE, D. (2007). The MUC1 and galectin-3 oncoproteins function in a microRNAdependent regulatory loop. Mol Cell 27: 992-1004.

REIS, C. A., DAVID, L., SEIXAS, M., BURCHELL, J., SOBRINHO-SIMÕES, M.
(1998). Expression of fully and under-glycosylated forms of MUC1 mucin in gastric carcinoma. Int J Cancer 79: 402-410.

RUTTEMAN, G. R., FOEKENS, J.A., PORTENGEN, H., VOS, J. H., BLANKENSTEIN, M. A., TESKE, E., CORNELISSE, C. J., MISDORP, W. (1994). Expression o epidermal growth factor receptor (EGFR) in non-affected and tumorous mammary tissue of female dogs. Breast Cancer Res Treat 30: 139-146.

SALOMON, D. S., BRANDT, R., CIARDIELLO, F., NORMANNO, N. (1995). Epidermal growth factor-related peptides and their receptors in human malignancies. Crit Rev Oncol Hematol 19: 183-232.

SCHINDLBECK, C., STELLWAGEN, J., JESCHKE, U., KARSTEN, U., RACK, B. JANNI, W., JÜCKSTOCK, J., TULUSAN, A., SOMMER, H., FRIESE, K. (2008) Immunomagnetic enrichment of disseminated tumor cells in bone marrow and blood of breast cancer patients by the Thomsen-Friedenreich-Antigen. Clin Exp Metastasis 25: 233-240.

SEKO, A., OHKURA, T., KITAMURA, H., YONEZAWA, S., SATO, E., YAMASHITA K. (1996). Quantitative differences in GlcNAc:beta1>3 and GlcNAc:beta1>4 galactosyltransferase activities between human colonic adenocarcinomas and normal colonic mucosa. Cancer Res 56: 3468-3473.

SIPAUL, F., BIRCHALL, M., CORFIELD, A. 2011. What role do mucins have in the development of laryngeal squamous cell carcinoma? A systematic review. Eur Arch Otorhinolaryngol.

SÖDERBERG, O., GULLBERG, M., JARVIUS, M., RIDDERSTRÅLE, K., LEUCHOWIUS, K., JARVIUS, J., WESTER, K., HYDBRING, P., BAHRAM, F., LARSSON L., LANDEGREN, U. (2006). Direct observation of individual endogenous protein complexes in situ by proximity ligation. Nat Meth 3: 995-1000.

SÖNMEZ, H., SÜER, S., GÜNGÖR, Z., BALOGLU, H., KÖKOGLU, E. (1999), Tissue and serum sialidase levels in breast cancer. Cancer Lett 136:75-78.

STORR, S. J., ROYLE, L., CHAPMAN, C. J., HAMID, U. M., ROBERTSON, J. F. MURRAY, A., DWEK, R. A., RUDD, P. M. (2008). The O-linked glycosylation of secretory/shed MUC1 from an advanced breast cancer patient's serum. Glycobiology 18: 456-462.

VLADIMIROVA, V., WAHA, A., LÜCKERATH, K., PESHEVA, P., PROBSTMEIER R. (2008). Runx2 is expressed in human glioma cells and mediates the expression of galectin-3. J Neurosci Res 86: 2450-2461.

WANG, X., SCHNEIDER, A. (2010). HIF-2alpha-mediated activation of the epidermal growth factor receptor potentiates head and neck cancer cell migration in response to hypoxia. Carcinogenesis 31: 1202-1210.

WESSELING, J., VAN DER VALK, S. W., VOS, H. L., SONNENBERG, A., HILKENS J. (1995). Episialin (MUC1) overexpression inhibits integrin-mediated cell adhesion to extracellular matrix components. J Cell Biol 129: 255-265.

YU, L. G., ANDREWS, N., ZHAO, Q., MCKEAN, D., WILLIAMS, J. F., CONNOR, L. J., GERASIMENKO, O. V., HILKENS, J., HIRABAYASHI, J., KASAI, K., RHODES, J. M. (2007). Galectin-3 interaction with Thomsen-Friedenreich disaccharide on cancer-associated MUC1 causes increased cancer cell endothelial adhesion. $J$ Biol Chem 282: 773-781.

ZHAO, Q., GUO, X., NASH, G. B., STONE, P. C., HILKENS, J., RHODES, J. M. YU, L. G. (2009). Circulating galectin-3 promotes metastasis by modifying MUC1 localization on cancer cell surface. Cancer Res 69: 6799-6806.

ZHAO, Q., BARCLAY, M., HILKENS, J., GUO, X., BARROW, H., RHODES, J. M., YU, L. G. (2010). Interaction between circulating galectin-3 and cancer-associated MUC1 enhances tumour cell homotypic aggregation and prevents anoikis. $\mathrm{Mo}$ Cancer 9:15. 


\section{Further Related Reading, published previously in the Int. J. Dev. Biol.}

Epithelial-Mesenchymal Transitions in development and disease: old views and new perspectives M. Angela Nieto

Int. J. Dev. Biol. (2009) 53: 1541-1547

Cadherin-mediated cell-cell adhesion and tissue segregation in relation to malignancy Ramsey A. Foty and Malcolm S. Steinberg

Int. J. Dev. Biol. (2004) 48: 397-409

Expression of galectin-7 during epithelial development coincides with the onset of stratification P M Timmons, C Colnot, I Cail, F Poirier and T Magnaldo

Int. J. Dev. Biol. (1999) 43: 229-235

Expression of galectin-1 in the mouse olfactory system J Tenne-Brown, A C Puche and B Key

Int. J. Dev. Biol. (1998) 42: 791-799

Adult epidermal keratinocytes are endowed with pilosebaceous forming abilities C Ferraris, B A Bernard and D Dhouailly

Int. J. Dev. Biol. (1997) 41: 491-498

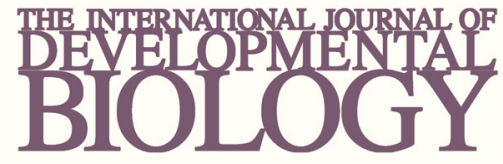

Volume 54 Nos. $6 / 7$
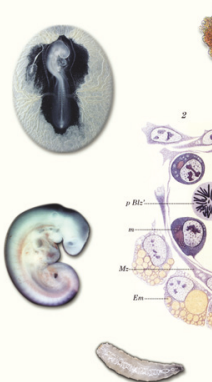

Developmental Hematopoiesis
Special Issue
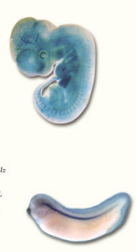

(2) 20.
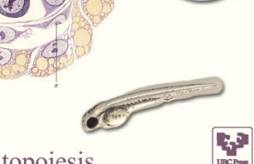

5 yr ISI Impact Factor $(2010)=2.961$
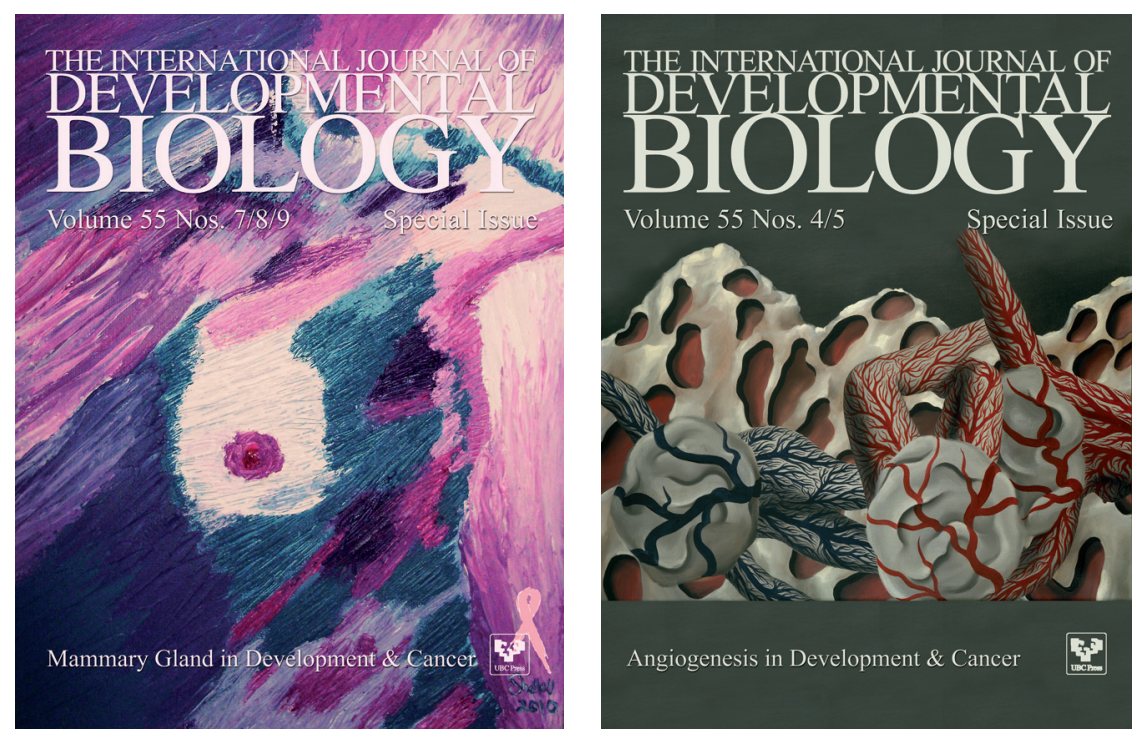